\title{
An application of Water Quality Index (WQI) and multivariate statistics to evaluate the water quality around Maddhapara Granite Mining Industrial Area, Dinajpur, Bangladesh
}

\author{
M. Farhad Howladar, Md. Abdullah Al Numanbakth and Mohammed Omar Faruque
}

\begin{abstract}
Background: Pure water is an absolutely necessary component of the earth not only for life but also for sustainable socio-economic development of today's civilization. The aim of this study was to analysis the quality of water resources and to investigate the influences of mining activities on water quality around the Maddhapara Granite Mining area, Dinajpur, Bangladesh.

Result: 31 samples from surface and groundwater were collected from this selected area to assess their hydrochemistry, suitability, and their possible sources of contamination. Consequently, in the case of physico-chemical analysis, the 24 parameters such as $\mathrm{P}^{\mathrm{H}}$, Electrical Conductivity, $\mathrm{TDS}, \mathrm{TH}, \mathrm{Ca}^{2+}, \mathrm{Mg}^{2+}, \mathrm{K}^{+}, \mathrm{Cd}^{2+}, \mathrm{Cr}^{3+}, \mathrm{Cl}^{-}, \mathrm{SO}_{4}^{2-}, \mathrm{PO}_{4}^{3-}, \mathrm{NH}_{4}^{+}, \mathrm{NO}_{3}^{-}$, $\mathrm{HCO}_{3}^{-}$etc. were analyzed in laboratory. Multivariate statistical methods were adopted for determining the water quality and their sources of contamination. The Gibbs ratio plot suggests that most of the samples fall in the rock dominance fields and some are in the precipitation dominance field. Cluster analysis confirms that three main groups of water samples where cluster I includes $70.97 \%$ of water samples, cluster II and cluster III includes rest 22.58 and $6.45 \%$ of the water samples respectively. Factor Analysis/Principal Component Analysis (FA/PCA) illustrates five factors extracted which explain $75.89 \%$ of the total variance.

Conclusion: The collective results of multivariate analysis and Water Quality Index implies that most of the areas around the mining area are dominated by the good to excellent quality water for different purposes. In addition, the results of this research will then be helpful to estimate the major sources of contamination in different areas within the framework of activities intending to improve the quality of water.
\end{abstract}

Keywords: Maddhapara Granite Mine, Hydrochemistry, Multivariate statistical methods, Water Quality Index, Contamination sources, Water quality for various uses

\section{Background}

Mining is one of the major anthropogenic activities which are liable for deteriorating the quality of water, soil as well as the environmental ecosystem not only in the surrounding area but also can far away with the help of river and stream flow. Anthropogenic activities can adversely affect water quality by introducing contaminants, such as metals

\footnotetext{
*Correspondence: farhadpme@gmail.com; farhad-pme@sust.edu Department of Petroleum and Mining Engineering, Shahjalal University of Science and Technology, Sylhet 3114, Bangladesh
}

and metalloids, and by enhancing natural processes, such as acid drainage generation (Gomshei and Allen 2000; Zhu and Anderson 2002; Edraki et al. 2005; Ribeiro et al. 2014). The availability of good quality water is vital for life, wellbeing, food and socio-economic development of mankind and it is generally obtained from two principal natural sources: surface water such as fresh water lakes, rivers, streams etc. and ground water such as borehole water and well water (McMurry and Fay 2004; Mendie 2005; Boateng et al. 2016). However, poor contaminated water can be threaten to health, more over to the subsistence 
of the biotic integrity and therefore hinders the ecosystem services and functions of aquatic ecosystems. On the other hand, water is necessary and an unavoidable element for domestic and industrial purposes because of its numerous physical and chemical both quantitative and qualitative characteristics. Maddhapara Granite Mining has been running since 2007 by adopting room and pillar sublevel stopping method in order to extract of hard rock commercially which are predominantly composed of diorite, quartz diorite and granite. However, rock storage as well as rock pilling is very ubiquitous features around the mine area. Surface waters are more vulnerable to pollution due to their easy accessibility for disposal of wastewaters (Singh et al. 2004; Bu et al. 2009; Hossain et al. 2010; Howladar 2013; Howladar et al. 2013, 2014). Prevention and control of the surface water pollution must rely on the reliable information of water quality and identification of pollutant sources (Simeonov et al. 2003; Shrestha and Kazama 2007; Bu et al. 2009; Howladar et al. 2017; Howladar 2017). Groundwater moves through porespaces within rocks and reacts with minerals that make up the rocks in the course of migration (Amadi et al. 2012; Boateng et al. 2016). Groundwater quality in any locality takes after the chemical composition of the aquifer through which it migrates in accordance with the hydrological cycle and flow direction (Offodile 1983; Amadi et al. 2010; Boateng et al. 2016). The aim of this study is to evaluate the hydrochemical characteristics, water quality, contamination as well as sources of contamination of ground and surface water around Maddhapara Granite Mining Industrial Area, Northwest Bangladesh.

\section{Location and geographic environment of the study area}

Location and climatic characteristics of study area

The Maddhapara Granite Mine area lies within Latitudes $25^{\circ} 33^{\prime} 15^{\prime \prime} \mathrm{N}$ to $25^{\circ} 34^{\prime} 13^{\prime \prime} \mathrm{N}$ and Longitude $89^{\circ}$ $3^{\prime} 30^{\prime \prime} \mathrm{E}$ to $89^{\circ} 4^{\prime} 53^{\prime \prime} \mathrm{E}$ (Fig. 1). Maddhapara is located in Parbottipur upazila of Dinajpur district of the northern part of Bangladesh. Maddhapara Granite Mine area is $330 \mathrm{~km}$ away from the capital city, Dhaka of Bangladesh. Bangladesh has a tropical monsoon climate characterized by variations in rainfall, high temperatures, and high humidity. The climate of the study area is described by considering hot season in summer, moderate season in monsoon and cool season in winter. The temperature and humidity records in the recent years are plotted in Fig. 2a, b, respectively.

\section{Geology of study area}

Bangladesh is divided into two main tectonic divisions namely (1) The Precambrian Indian Platform (Northwest part) and (2) The basin or geosyncline (south-east

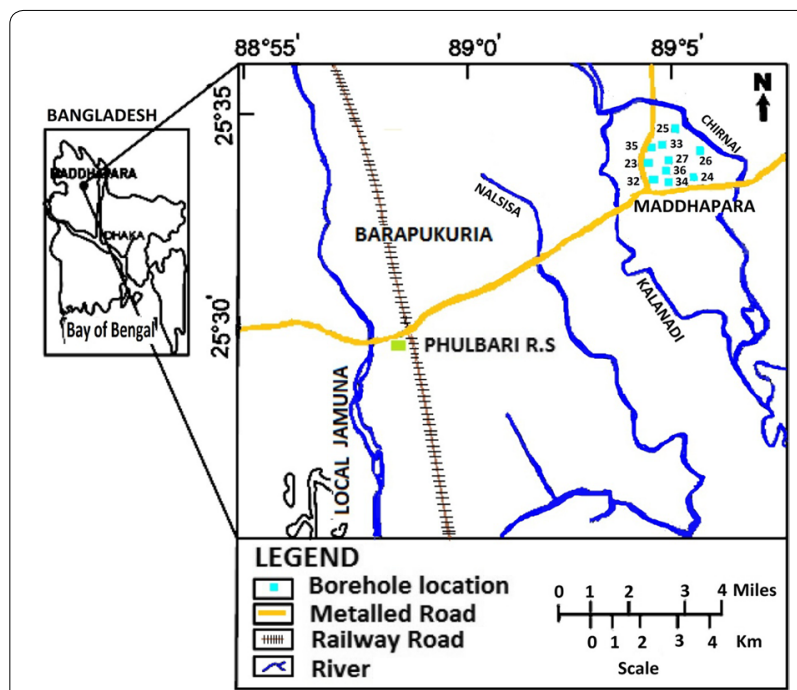

Fig. 1 Location map of Maddhapara Hardrock Mining Project (MHRMP) area (NAMNAM 2000)

part) based on the basic structural or tectonic framework. A north-east to south-east aligned about $25 \mathrm{~km}$ wide zone separates the Precambrian Platform from the Basin part. Again, the Precambrian Indian platform is subdivided into (1) Rangpur Saddle, and (2) Bogra shelf; whereas the basin or geosyncline is subdivided into (1) Bengal for deep and (2) folded belt. Maddhapara hardrock mining area is located in the Rangpur Saddle. The distinguish features of this area are that it's sedimentary cover is very thin and basement lies at shallow depth. The Dome shaped Maddhapara Hard Rock Mining (MHRM) area is located in the Barind Tract of Pleistocene era, drained by Jamuna and Jamuneswari river in the west and east sides respectively. Two rivers named Kalanadi and Chirnai flow from west to south-east and north to south-east directions respectively and meet with Jamuneswari river separately. Due to the tectonic activity during the Permo-Carboniferous (about 300 million years ago), the subsurface features of the Maddhapara mine area is highly fractured and fault controlled. At shallow depth $(128 \mathrm{~m})$ a basement high is located at Maddhapara. This high is limited on the east by a Northwest-Southeast trending fault. The Basement rock of the Maddhapara is below the layers of alluvium soil $(0-0.5 \mathrm{~m})$, Madhupur Clay (0.5-6 m), Dupitila Formation (6-120 m), Tura Formation (120-141 m, Gondwana Group (160-259.6 m). Basement is of the Archean era and subdivided into the kaolinized granodiorite, the weathered granodiorite and the fresh granodiorite. Dykes of micro-granodiorite, fine grained silicified whitish granite and pegmatite is thinly inserted in the basement. According to the Geological survey of Bangladesh, the age of granodiorite in 

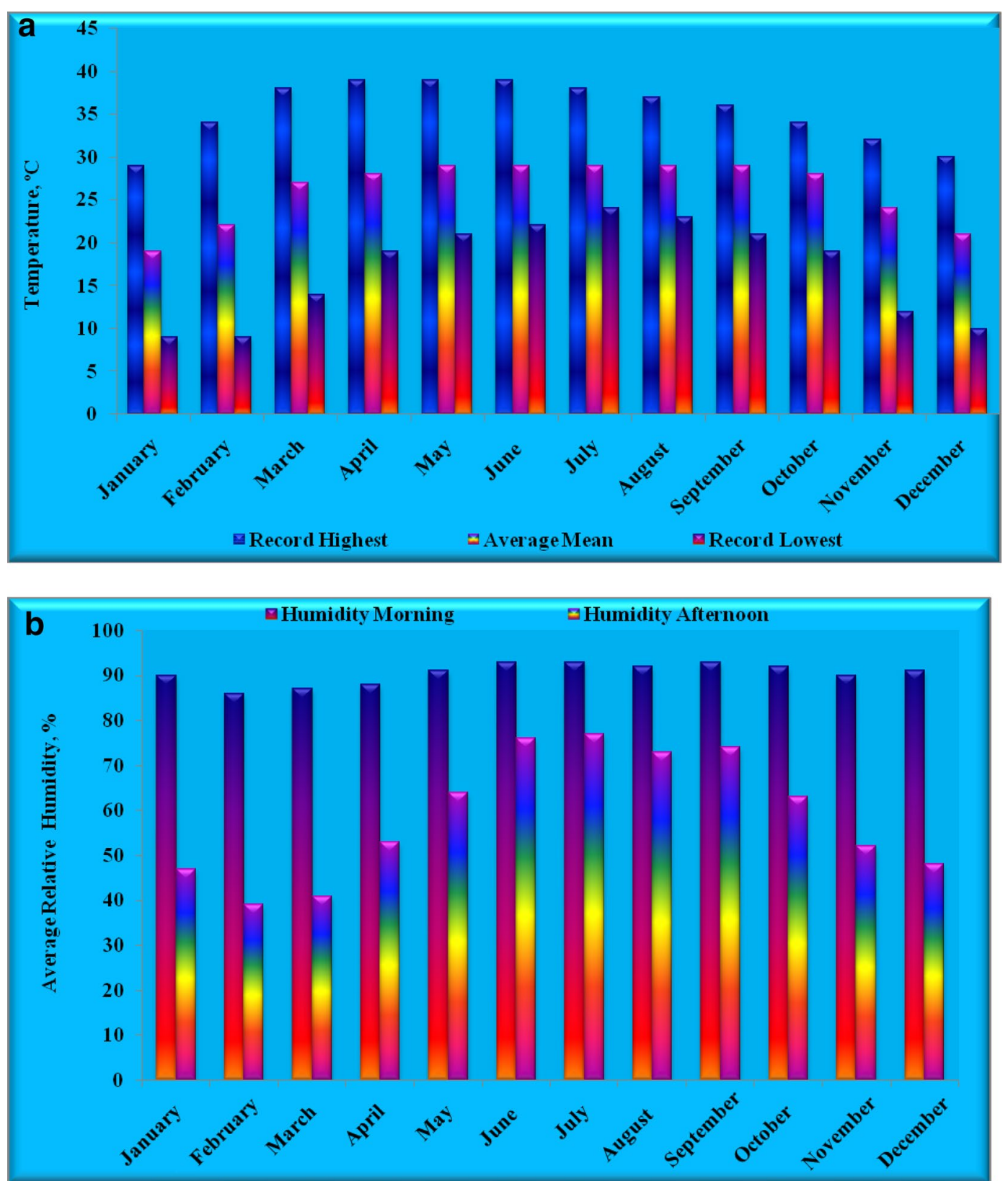

Fig. 2 a Column diagram of monthly recorded highest, lowest and average temperature. b Column diagram of monthly recorded average relative humidity \% in morning and in afternoon

the hardrock deposit is the Archean Era. The Geological cross section across the MHRM boreholes is shown in Fig. 3.

\section{Hydrology of study area}

There are two aquifer systems (Fig. 4) in the Maddhapara Granite Mining area (i) Porous aquifer or Upper aquifer and (ii) Fissure aquifer or Lower aquifer. The Porous aquifer comprises Dupi Tila, Tura Sandstone and Gondwana formations (Fig. 4). The Dupitila formation consists of yellowish brown fine to medium grained sands and coarse grained pebbly sands in places. The Tura formation comprises a fine to medium sands and in places pebbles. Gondwana formation is composed of well-rounded fine to medium grained feldspathic sandstone and pebbles in places. Thus this all form an overburden aquifer. The fissure aquifer is composed of the Archean weathered green granodiorite and fresh rocks with numerous fractures, 


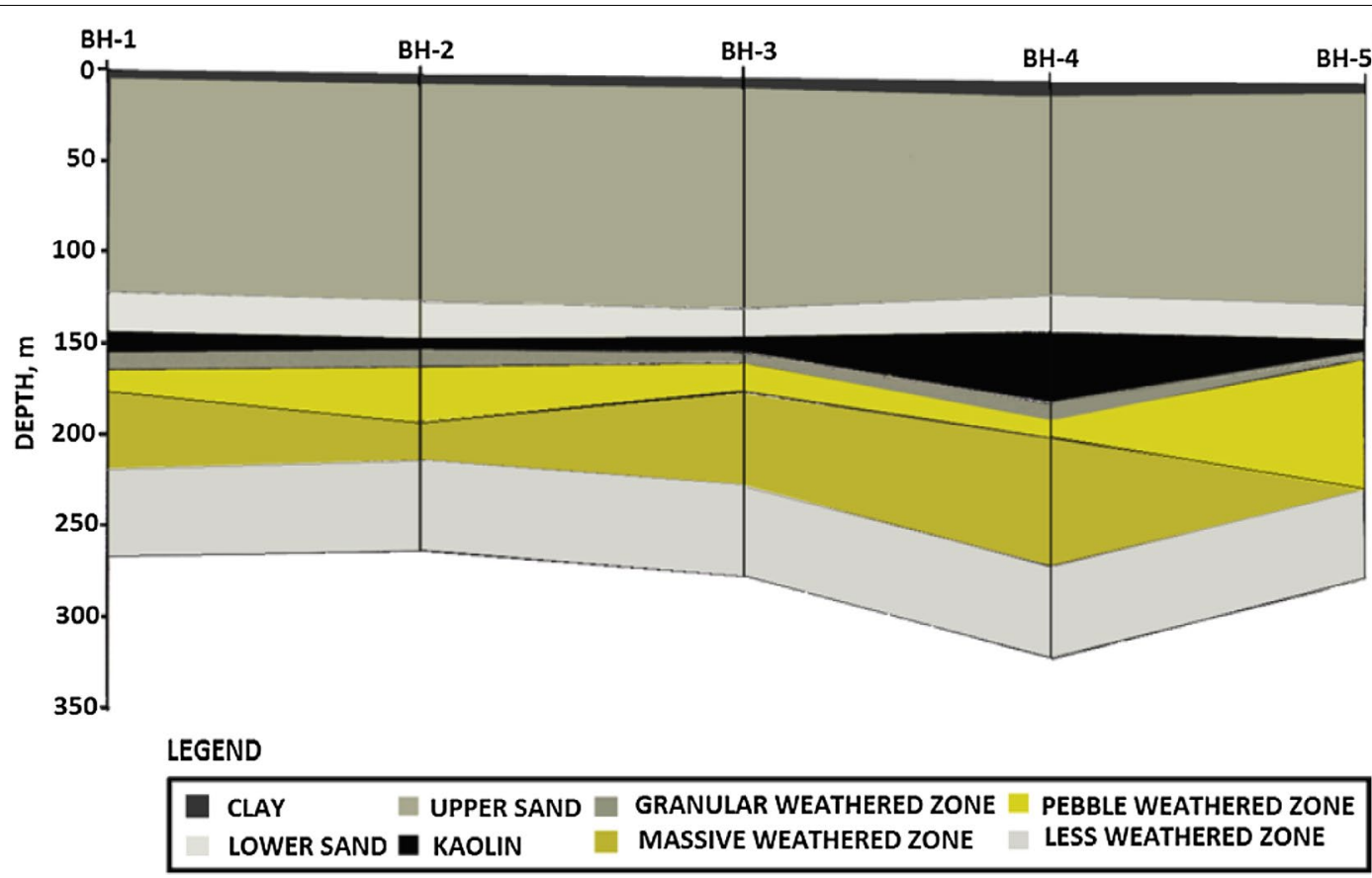

Fig. 3 Geological cross section across the MHRMP boreholes [Modified after Rahman (1987)]

joints, fissures. The white clay separates the two aquifers. The upper aquifer is about $125 \mathrm{~m}$ thick, which lies below ground level in most of the area. The flow of water in the confined basement aquifer takes place principally through interconnected fractures. The development of the mine is retarded due to flooding of underground mine area, which is drained out regularly for uninterrupted development of the mine. The Precambrian crystalline basement occurs at a depth of about $130 \mathrm{~m}$ below ground level (Bashar et al. 2008).

\section{Methods}

\section{Field investigation and samples collection}

All thirty-one surface and groundwater samples were collected from different spots of the study area. Plastic bottles with proper washed have been used for collecting the water samples.

Latitude and Longitude of the sample collecting spots were recorded with the help of GPS reading. The collected water samples were marked by MRS- 1 to MRS- 18 wherein MRS-2, MRS-3, MRS-5 and MRS-11 were collected from surface water and remaining were collected from underground water. Again, other water samples were noted by MDS-19 to MDS-31 wherein MDS-24, MDS-26 and MDS-30 were collected from surface water and rest were collected from underground water. The location of the samples collecting spots around the mine area are shown in Fig. 5.

\section{Laboratory analysis}

Different parameters of water samples were analyzed carefully in the Central Chemical Research Laboratory of Water Treatment Plant, Barapukuria Coal based Thermal Power Plant and Bangladesh Power Development Board (BPDB), Dinajpur. Demineralized water was used throughout the analysis wherever applicable. The electrical conductivity (EC), $\mathrm{P}^{\mathrm{H}}$, Total Dissolved solids (TDS) and temperature $(\mathrm{T})$ of all the samples were measured by portable digital meter in the field. Sodium $\left(\mathrm{Na}^{+}\right)$and potassium $\left(\mathrm{K}^{+}\right)$were measured using flame photometer (Model No. PEP 7 and PEP 7/C). Calcium $\left(\mathrm{Ca}^{2+}\right)$ and magnesium $\left(\mathrm{Mg}^{2+}\right)$ were determined titrimetrically using standard EDTA solution. Chloride $\left(\mathrm{Cl}^{-}\right)$was determined by ion selective electrode method (Cole-Parmer iodine electrode, model no. 27502-13). It was also cross checked by volumetric analysis of the water samples. Bicarbonate $\left(\mathrm{HCO}_{3}^{-}\right)$concentrations of the water was determined by potentiometric titration method. Sulphate $\left(\mathrm{SO}_{4}^{2-}\right)$, orthophosphate $\left(\mathrm{PO}_{4}^{3-}\right)$, and dissolved silica $\left(\mathrm{as}^{\mathrm{SiO}}{ }_{2}\right)$ analyses of the water samples were carried out using UV-visible spectrophotometer. Nitrate $\left(\mathrm{NO}_{3}^{-}\right)$was measured by using ion selective electrode methods (Cole-Parmer Iodine Electrode, model no. 27502-19). High purity analytical reagents were used throughout the study, and chemical standards for each element when necessary were prepared separately. $\mathrm{As}^{3+}$ was test by using the Hach EZ Arsenic test kit (calt. no. 28228-00). However 

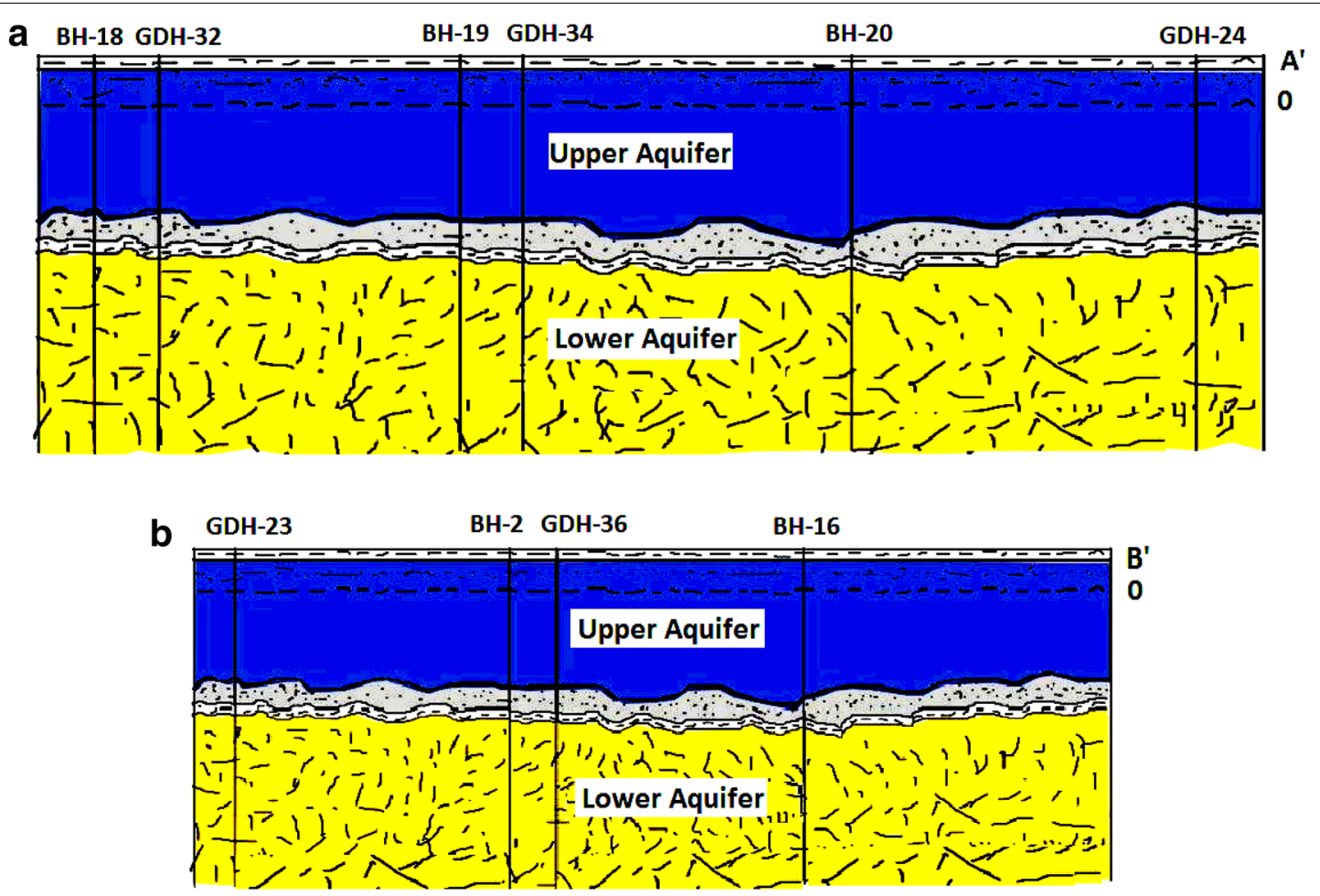

\section{LEGEND}
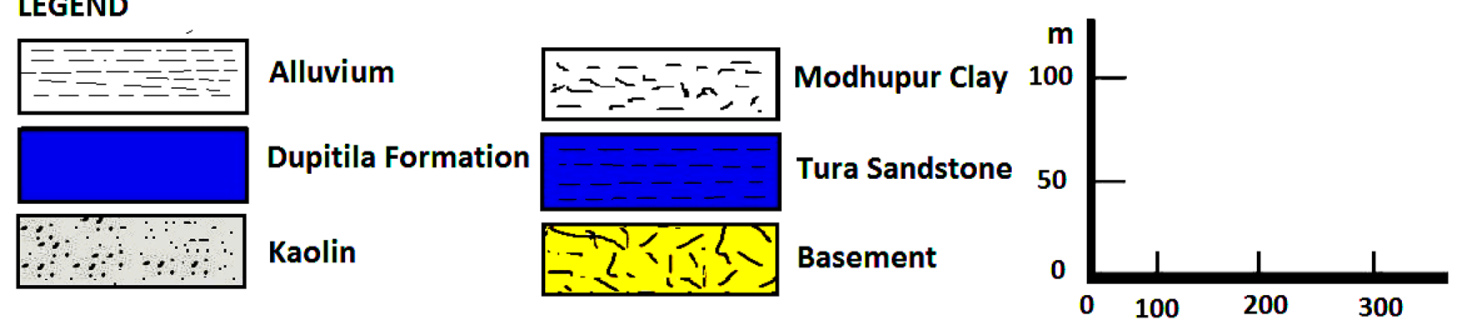

Fig. 4 Hydrogeological cross section of the Maddhapara Mine area [Modified after Bashar et al. (2008)]

the similar physical and analytical procedure was previously reported by many researcher such as Howladar et al. (2013, 2014); Howladar and Rahman (2016); Martinello et al. (2014); Ramos et al. (2015); RodriguezIruretagiiena et al. (2015); Sanchís et al. (2013); Tezza et al. (2015) and so on.

\section{Water Quality Index (WQI)}

The Water Quality Index (WQI) analysis provides a comprehensive picture of the quality of surface and ground water for most domestic uses. WQI is defined as a rating that reflects the composite influence of different water quality parameters (Sahu and Sikdar 2008). It is an important parameter for assessing groundwater quality and its suitability for drinking purposes (Tiwari and
Mishra 1985; Singh 1992; Subba 1997; Mishra and Patel 2001; Naik and Purohit 2001; Avvannavar and Shrihari 2008; Pawar et al. 2014; Boateng et al. 2016).

Water Quality Index (WQI) is a single value expression that numerically summarizes multiple water quality parameters. It is calculated from the point of view that a lower value of it signifies less deviation from the recommended values of parameters included and more good quality water for human consumption or vice versa. In order to calculate the WQI in this study, 12 physicochemical parameters have been considered. Relative weight $\left(\mathrm{w}_{\mathrm{j}}\right)$ is assigned with respect to their perceived effects on primary health and relative importance in the overall water quality. The parameters which have major impacts on water quality (viz., TDS, $\mathrm{Cl}^{-}, \mathrm{SO}_{4}^{2-}, \mathrm{NO}_{3}^{-}$are assigned to the highest weight of 5 and 


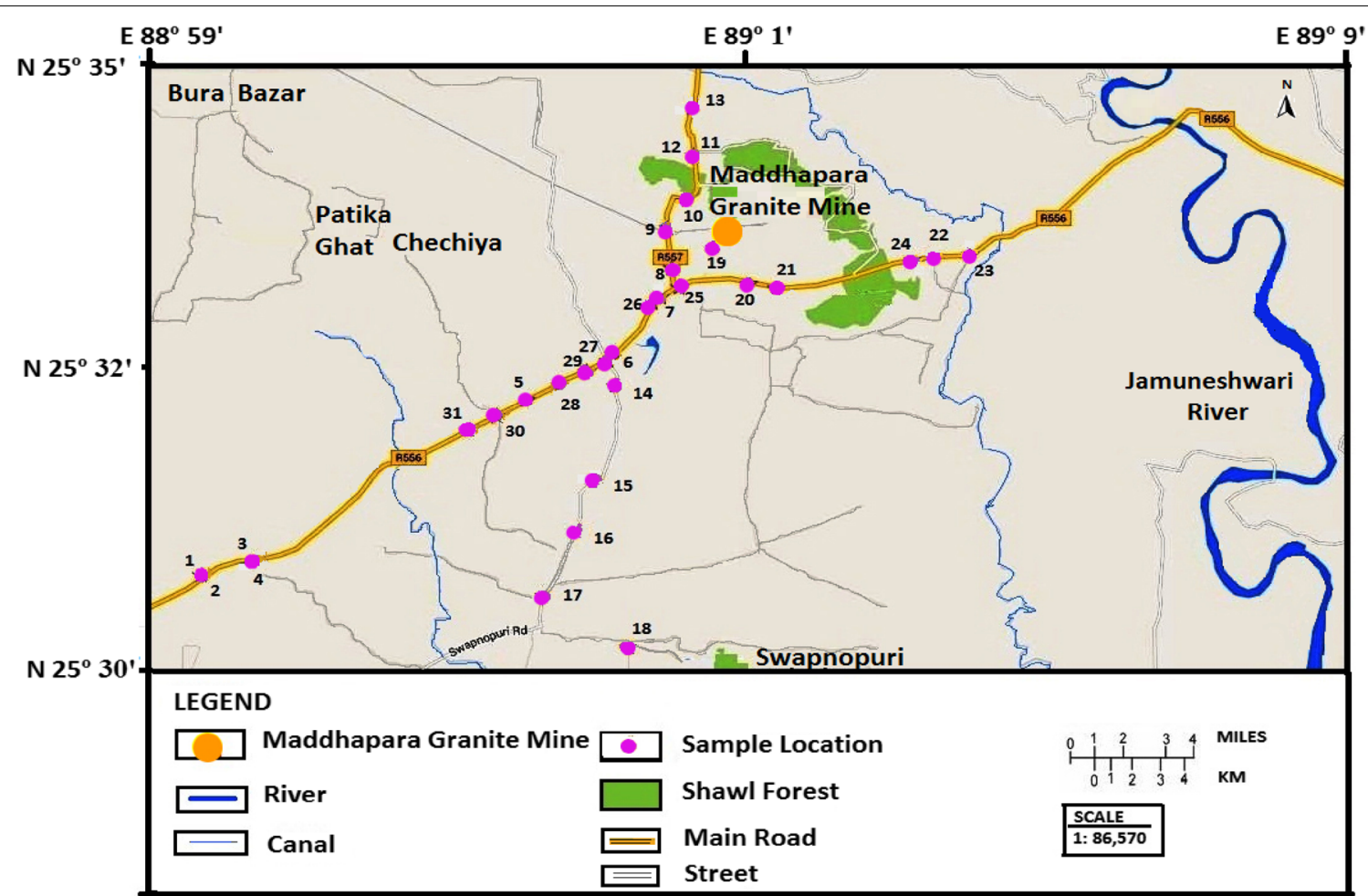

Fig. 5 Location map of the samples

a minimum of 1 is assigned to parameters which are considered of less impacts (viz., $\mathrm{HCO}_{3}^{-}$and $\mathrm{PO}_{4}^{3-}$ ) on the water quality. Other parameters such as $\mathrm{P}^{\mathrm{H}}, \mathrm{EC}, \mathrm{TH}, \mathrm{Ca}^{2+}, \mathrm{Mg}^{2+}$ and $\mathrm{K}^{+}$are assigned a weight between 2 and 4 depending on their importance in the overall water quality.

The relative weight is then calculated by using the Eq. (1):

$$
\mathrm{W}_{\mathrm{i}}=\frac{\mathrm{w}_{1}}{\sum_{\mathrm{i}=1}^{\mathrm{n}} \mathrm{W}_{1}}
$$

where $W_{i}$ is the relative weight of ith parameter, $w_{i}$ is the weight of each parameter, and $\mathrm{n}$ is the number of parameters. The assigned weight, WHO standard value and calculated relative weight are summarized in Table 1 . The quality rating scale for each parameter is calculated by using Eq. (2):

$$
\mathrm{q}_{\mathrm{i}}=\frac{c_{i}}{s_{i}} \times 100
$$

where $\mathrm{q}_{\mathrm{i}}$ is the quality rating, $\mathrm{C}_{\mathrm{i}}$ is the concentration $(\mathrm{mg} / \mathrm{L})$ or value of each parameter and $\mathrm{S}_{\mathrm{i}}$ is the World Health Organization standard of respective parameter.

For computing the WQI, sub-index (SI) is calculated for each parameter using Eq. (3) and the WQI is then calculated by Eq. (4).
Table 1 Relative weight of some physicochemical parameters and WHO water quality standards

\begin{tabular}{llll}
\hline Parameters & $\begin{array}{l}\text { WHO } \\
\text { standards (2011) }\end{array}$ & $\begin{array}{l}\text { Weight } \\
\left(\mathbf{w}_{\mathbf{i}}\right)\end{array}$ & $\begin{array}{l}\text { Relative weight } \\
\mathbf{W}_{\mathbf{i}}=\frac{\mathbf{w}_{\mathbf{1}}}{\sum_{\mathbf{i}=1}^{\mathbf{n}} \mathbf{w}_{\mathbf{1}}}\end{array}$ \\
\hline $\mathrm{EC}$ & 500 & 4 & 0.097560976 \\
$\mathrm{TDS}$ & 500 & 5 & 0.121951220 \\
$\mathrm{TH}$ & 100 & 3 & 0.073170732 \\
$\mathrm{Ca}^{2+}$ & 75 & 3 & 0.073170732 \\
$\mathrm{Mg}^{2+}$ & 50 & 3 & 0.073170732 \\
$\mathrm{~K}^{+}$ & 10 & 2 & 0.048780488 \\
$\mathrm{Cl}^{-}$ & 250 & 5 & 0.121951220 \\
$\mathrm{HCO}_{3}^{-}$ & 500 & 1 & 0.024390244 \\
$\mathrm{SO}_{4}^{2-}$ & 250 & 5 & 0.121951220 \\
$\mathrm{NO}_{3}^{-}$ & 45 & 5 & 0.121951220 \\
$\mathrm{PO}_{4}^{3-}$ & 0.5 & 1 & 0.024390244 \\
$\mathrm{PH}^{\mathrm{H}}$ & $6.5-8.5$ & 4 & 0.097560976 \\
& & $\sum w_{i}=41$ & $\sum w_{i}=1.00$ \\
\hline
\end{tabular}

$$
\mathrm{SI}_{\mathrm{i}}=\mathrm{W}_{\mathrm{i}} \times \mathrm{q}_{\mathrm{i}}
$$

where $\mathrm{SI}_{\mathrm{i}}$ is the sub-index of the ith parameter.

$$
\mathrm{WQI}=\sum \mathrm{SI}_{\mathrm{i}}
$$


Boateng et al. (2016) have classified the water quality into five categories as excellent, good, poor, very poor, and unsuitable for human consumption based on WQI values as shown in Table 2 .

\section{Multivariate statistical analysis}

Multivariate statistical analysis is a useful tool for the assessment of the water quality where a lot of variables are responsible for influencing the water quality. The most common statistical analysis that are widely used to identify the dominating components and sources that explain the variations in the water quality and their impacts on water environments are hierarchical cluster analysis, factor analysis/principal component analysis (FA/PCA), correlation matrix analysis. Cluster analysis comprises of multivariate methods which are used to find true groups of data. In clustering, the objects are grouped such that similar objects fall into the same class (Oketola et al. 2013). The main aim of the cluster analysis is to join the homogeneous groups which are most similar to each other considering some of the certain properties. Hierarchical clustering joins the most similar observations and successively the next most similar observations (Oketola et al. 2013). Statistica 8.0 software was used for analyzing the cluster analysis as well as the principal component analysis. Principal component analysis is a powerful technique for pattern recognition that attempts to explain the variance of a large set of inter-correlated variables and transform them into a smaller set of independent (uncorrelated) variables $(\mathrm{Bu}$ et al. 2009) which can be computed as:

Table 2 Water quality classification for drinking purposes based on the WQI values (Boateng et al. 2016)

\begin{tabular}{ll}
\hline Range & Type of water \\
\hline$<50$ & Excellent \\
$50-100$ & Good \\
$100.1-200$ & Poor \\
$200.1-300$ & Very poor \\
$>300$ & Unsuitable \\
\hline
\end{tabular}

$Z_{i j}=a_{i 1} X_{1 j}+a_{i 2} X_{2 j}+a_{i 3} X_{3 j}+\cdots+a_{i m} X_{m j}$

Factor analysis (FA) generally helps to reduce and simplify the outcome from the PCA. Hence the FA can be calculated as:

$Z j i=a_{f 1} f_{1 i}+a_{f 2} f_{2 i}+a_{f 3} f_{3 i}+\cdots+a_{f m} f_{m i}+e_{f i}$

where $\mathrm{z}, \mathrm{a}, \mathrm{i}, \mathrm{x}, \mathrm{m}, \mathrm{j}$, e and fare component score, factor loading, sample numbers, measured value of variable, total number of variables, other source of variation and the factor score, respectively. However, correlation matrix analysis shows the relation between any two parameters, its strengths and the direction of relationship in which they vary.

\section{Results and discussions}

Physicochemical characteristics of water samples

The physicochemical parameter analysis is the preliminary study by which the nature, quality and types of water can be identified. The summary of the values, average, variations, median of physicochemical parameters such as $\mathrm{P}^{\mathrm{H}}$, Electrical Conductivity (EC), turbidity, total alkalinity (TA), total hardness (TH), total dissolved solids (TDS) and soluble silica are tabulated in Table 3.

The $\mathrm{P}^{\mathrm{H}}$ value of the water samples ranged from 5.3 to 9.02 with an average value of 7.49 . The permissible limit of the $\mathrm{pH}$ for drinking water is 6.5-8.5 (WHO 2011). The $\mathrm{P}^{\mathrm{H}}$ levels of the most of the samples were found within the permissible limit for drinking purposes. The $\mathrm{P}^{\mathrm{H}}$ values lower than the 6.5 are considered as too acidic and unsuitable for drinking purposes. The lowest value of $\mathrm{P}^{\mathrm{H}}$ was recorded in surface water (MRS-5) which was open to the agricultural land near the mine area. Again, the $\mathrm{P}^{\mathrm{H}}$ values of water samples greater than 8.5 are too alkaline and are not suitable for human consumption. The highest value was recorded in groundwater (MDS-31). The electrical conductivity (EC) is the ability of water to pass electric current through it which is related to the concentration of the ionized substances dissolved in water and an indication of the salinity of water. The EC value in water samples ranged between 41 and $587 \mu \mathrm{S} / \mathrm{cm}$ with

Table 3 Statistical analysis of physicochemical parameters in water around the study area

\begin{tabular}{|c|c|c|c|c|c|c|c|}
\hline & Min. & Max. & Mean & Median & Std. deviation & Variance & WHO (2011) \\
\hline $\mathrm{P}^{\mathrm{H}}$ & 5.3 & 9.02 & 7.49 & 7.46 & 0.71 & 0.51 & $6.5-8.5$ \\
\hline EC & 41 & 587 & 147.2 & 112.4 & 113.65 & $12,915.95$ & 500 \\
\hline Turbidity & 3 & 45 & 10.74 & 7.00 & 10.69 & 114.33 & $<5$ \\
\hline $\mathrm{TA}$ & 5 & 88 & 29 & 19 & 22.19 & 492.4 & - \\
\hline $\mathrm{TH}$ & 2.5 & 87.5 & 22.74 & 15.5 & 20.44 & 417.81 & 100 \\
\hline TDS & 24 & 382 & 103.9 & 84.3 & 74.05 & 5483.33 & 500 \\
\hline Soluble silica & 11.9 & 53.8 & 28.82 & 32 & 9.9 & 98.08 & - \\
\hline
\end{tabular}


an average value of $147.2 \mu \mathrm{S} / \mathrm{cm}$. A lower EC value signifies less concentration of the dissolved ions and organic matters and vice versa. The lowest value of $41 \mu \mathrm{S} / \mathrm{cm}$ was recorded in surface water sample (MRS-5) and the highest value of $587 \mu \mathrm{S} / \mathrm{cm}$ was recorded in the groundwater samples (MRS-14). The recommended value of $\mathrm{EC}$ for drinking water purposes is $500 \mu \mathrm{S} / \mathrm{cm}$. Turbidity is a measure of the water cloudiness or haziness of water caused by large numbers of individual particles that are generally invisible to the naked eye. The turbidity of water was recorded between 3 NTU and 45 NTU with an average value of 10.74 NTU. The WHO (2011) recommends the turbidity of water should not exceed five NTU. Total alkalinity (TA) is a measure of water's resistances to change in $\mathrm{P}^{\mathrm{H}}$. It is the amount of alkali in the form of bi-carbonates, carbonates and hydroxides present in the water. The TA was varied in the water samples from 5 to $88 \mathrm{mg} / \mathrm{L}\left(\right.$ as $\mathrm{CaCO}_{3}$ ) with an average of $29.64 \mathrm{mg} / \mathrm{L}$ (as $\mathrm{CaCO}_{3}$ ). The suggested alkalinity in our drinking water is $20-200 \mathrm{mg} / \mathrm{L}$. Water with low alkalinity can be corrosive and can irritate the eyes. Water with high alkalinity has a soda like taste, can dry out skin and can cause scaling on fixtures and throughout water distribution system. The hardness of water is due to the presence of the calcium and magnesium ions containing minerals that are naturally present in the water. Hard water is formed when water is got mixed with the limestone and chalk which are highly enriched with calcium and magnesium carbonates and bi-carbonates. The Total Hardness $(\mathrm{TH})$ values in the water samples ranged from 2.5 to $87.5 \mathrm{mg} / \mathrm{L}$ with an average of $22.74 \mathrm{mg} / \mathrm{L}\left(\right.$ as $\mathrm{CaCO}_{3}$ ). The maximum permissible limit of $\mathrm{TH}$ for drinking water is $500 \mathrm{mg} / \mathrm{L}$ and the most desirable limit is $100 \mathrm{mg} / \mathrm{L}$ as per the WHO International standards (2011). Total dissolved solids (TDS) is a measure of the inorganic salts and small amounts of the organic matter present in solution in water. So, it is related to the conductivity of the water because of effect of dissolved ions though their relation is not constant. Total dissolved solids in water samples ranged from 24 to $382 \mathrm{mg} / \mathrm{L}$ with an average of $100.9 \mathrm{mg} / \mathrm{L}$. According to WHO (1996), the presence of dissolved solids in water may affect its taste. Moreover, the palatability of drinking water may be classified as excellent $(<300 \mathrm{mg} / \mathrm{L})$, good $(300-600 \mathrm{mg} / \mathrm{L})$, fair $(600-$ $900 \mathrm{mg} / \mathrm{L})$, poor $(900-1200 \mathrm{mg} / \mathrm{L})$ and unacceptable $(>1200 \mathrm{mg} / \mathrm{L})$. Water with low TDS concentrations, may also be unsuitable for drinking due its flat, insipid taste. The concentration of the soluble silica ranged from 11.9 to $53.84 \mathrm{mg} / \mathrm{L}$ with an average of $28.82 \mathrm{mg} / \mathrm{L}$. It is very higher than the natural limit $(5-25 \mathrm{mg} / \mathrm{L})$ in that area which strongly supports the dissolution and the weathering effect of the hardrock that are extracted and stock filled in the mine area which contains $50.17-74.7 \%$ (by weight) of $\mathrm{SiO}_{2}$. Though, silica ingested orally is essentially non-toxic with an $\mathrm{LD}_{50}$ of $5 \mathrm{~g} / \mathrm{kg}$, this result gives a massage that there may also a great amount of silica dust in the air around the mine site which can lead to silicosis, bronchitis or cancer for inhaling with finely divided crystalline silica dust. Silicosis is a serious lung disease caused by the accumulation of silica dust in the lungs (Gbadebo et al. 2013).

\section{Abundances of different ions}

Statistical analysis of the concentration of different parameter in water sample around the study area and corresponding WHO recommended value of those different parameters are tabulated in Table 4. Calcium is a major cations found in water which makes water hard. Calcium constitutes our body's bones and teeth and works as a structural elements of our body. The risk of osteoporosis, nephrolithiasis (kidney stones), colorectal cancer, hypertension and stroke, coronary artery disease, insulin resistance and obesity increases because of inadequate intake of calcium. The WHO guideline value of $\mathrm{Ca}^{2+}$ for drinking purpose is $75 \mathrm{mg} / \mathrm{L}$. The concentration $\mathrm{Ca}^{2+}$ in the water samples ranged from 1.3 to $55 \mathrm{mg} / \mathrm{L}$ with an average of $15.06 \mathrm{mg} / \mathrm{L}$. The results show that all samples were within the guideline value. The second most abundant inorganic ion that present in water is magnesium. The concentration of $\mathrm{Mg}^{2+}$ in the water samples varied from 1 to $41 \mathrm{mg} / \mathrm{L}$ with an average value of $10.56 \mathrm{mg} / \mathrm{L}$. The WHO recommended value for $\mathrm{Mg}^{2+}$ concentration is $50 \mathrm{mg} / \mathrm{L}$. All samples were found within the WHO (2011) permissible limits for calcium and magnesium. Both calcium and magnesium ions generally originate from the carbonate minerals, such as calcite and dolomite. The concentration of $\mathrm{Na}^{+}$in the water ranged from 2.1 to $53 \mathrm{mg} / \mathrm{L}$ with an average value of $14.34 \mathrm{mg} / \mathrm{L}$. It is an essential element for human body for keeping body in proper working conditions. Sodium helps in maintaining blood pressure, controlling fluid levels, as well as keeping normal nerve and muscle functions. The spatial variation of the sodium ion concentration indicates localized weathering of feldspar (plagioclase bearing) rocks present in the granite rocks and may also due to the over exploitation of groundwater because of mining and basic consumption needs. EQS (2004) suggests a desirable sodium concentration of $100 \mathrm{mg} / \mathrm{L}$ in water for drinking purposes. Potassium $\left(\mathrm{K}^{+}\right)$concentration in water samples varied from 0.4 to $12.2 \mathrm{mg} / \mathrm{L}$ with a mean of $3.1 \mathrm{mg} / \mathrm{L}$ which had exceeded the WHO (2011) recommended potassium ion concentration in water of $10 \mathrm{mg} / \mathrm{L}$. The increased level of potassium may be due to both the dissolution and weathering of the K-feldspars and clay minerals from the aquifer matrix as the granite rock in the mine area that is extracted is highly rich 
Table 4 Statistical analysis of the ion concentration in water around the study area, Dinajpur

\begin{tabular}{|c|c|c|c|c|c|c|c|}
\hline lons & Min. & Max. & Mean & Median & Std. deviation & Variance & WHO (2011) \\
\hline $\mathrm{Ca}^{2+}$ & 1.3 & 55 & 15.06 & 10 & 14.01 & 196.4 & 75 \\
\hline $\mathrm{Mg}^{2+}$ & 1 & 41 & 10.56 & 5.75 & 10.16 & 103.24 & 50 \\
\hline $\mathrm{Na}^{+}$ & 2.1 & 53 & 14.34 & 13.8 & 10.58 & 111.97 & - \\
\hline $\mathrm{K}^{+}$ & 0.4 & 12.2 & 3.1 & 2.7 & 2.53 & 6.41 & 10 \\
\hline $\mathrm{Fe}^{3+}$ & 0.09 & 0.92 & 0.34 & 0.24 & 0.23 & 0.05 & - \\
\hline $\mathrm{As}^{3+}$ & 0 & 0.0017 & 0.001 & 0.0011 & 0.0005 & 0 & $<0.01$ \\
\hline $\mathrm{Cd}^{2+}$ & 0.0008 & 0.0042 & 0.002 & 0.002 & 0.001 & 0 & 0.05 \\
\hline $\mathrm{Zn}^{2+}$ & 0.08 & 0.32 & 0.15 & 0.13 & 0.06 & 0 & 3 \\
\hline $\mathrm{Cr}^{3+}$ & 0 & 0.015 & 0.0023 & 0.002 & 0.003 & 0.002 & $<0.05$ \\
\hline $\mathrm{SO}_{4}^{2+}$ & 0.08 & 10 & 0.86 & 0.34 & 1.86 & 3.44 & 250 \\
\hline $\mathrm{PO}_{4}^{3-}$ & 0.08 & 2.3 & 0.48 & 0.34 & 0.5 & 0.25 & 2.5 \\
\hline $\mathrm{HCO}_{3}^{-}$ & 5 & 87.5 & 28.31 & 19 & 20.94 & 438.51 & 500 \\
\hline $\mathrm{NO}_{3}^{-}$ & 0.07 & 0.71 & 0.35 & 0.33 & 0.16 & 0.03 & 45 \\
\hline $\mathrm{Cl}^{-}$ & 0.71 & 73.84 & 9.79 & 4.26 & 14.4 & 207.48 & 250 \\
\hline $\mathrm{NH}_{4}^{+}$ & 0.22 & 1.07 & 0.7 & 0.7 & 0.24 & 0.06 & 35 \\
\hline $\mathrm{CO}_{3}^{2-}$ & 4.3 & 18 & 9.35 & 8.95 & 3 & 9.03 & - \\
\hline
\end{tabular}

with feldspar minerals. Iron ion concentration in water samples in the form of $\mathrm{Fe}^{3+}$ varied from $0.09 \mathrm{mg} / \mathrm{L}$ to a maximum of $0.92 \mathrm{mg} / \mathrm{L}$ with a mean concentration of $0.34 \mathrm{mg} / \mathrm{L}$. It is essential for human body as it is needed in the transmission of oxygen in blood. However, excess iron in water can cause yellow, red, or brown strains on laundry, dishes, and plumbing fixtures such as sinks. Arsenic $\left(\mathrm{As}^{3+}\right)$ is a toxic metalloid, ubiquitous element in the environment and affecting over 150 million people worldwide through consumption of arsenic contaminated potable water (Ahmad and Qadir 2011; Rahman et al. 2009; Srivastava et al. 2015). Arsenic in water for drinking purpose should be below $0.01 \mathrm{mg} / \mathrm{L}$. However, the World Health Organization (WHO) recommended the arsenic concentration in the drinking water should not beyond $0.05 \mathrm{mg} / \mathrm{L}$. Arsenic $\left(\mathrm{As}^{3+}\right)$ concentration in the water samples varied from 0 to $0.0017 \mathrm{mg} / \mathrm{L}$ where the mean concentration was $0.001 \mathrm{mg} / \mathrm{L}$. Cadmium ion $\left(\mathrm{Cd}^{2+}\right)$ concentration in water varied from 0.001 to $0.004 \mathrm{mg} / \mathrm{L}$ with a mean value of $0.002 \mathrm{mg} / \mathrm{L}$. The WHO (2011) guideline value for cadmium concentration in water samples should be less than 0.01 . The concentration of zinc $\left(\mathrm{Zn}^{2+}\right)$ in water was found within the maximum permissible limit of $3 \mathrm{mg} / \mathrm{L}$ by the WHO (2011) and ranged from 0.08 to $0.32 \mathrm{mg} / \mathrm{L}$ with an average value of $0.15 \mathrm{mg} / \mathrm{L}$. According to WHO (1996), the concentration of chromium $\left(\mathrm{Cr}^{3+}\right)$ in drinking water should not be acceded over $0.05 \mathrm{mg} / \mathrm{L}$. The concentration of the $\mathrm{Cr}^{3+}$ in water samples varied from 0 to $0.015 \mathrm{mg} / \mathrm{L}$ with a mean value of $0.0023 \mathrm{mg} / \mathrm{L}$. Sulfates occur naturally in numerous minerals, including barite $\left(\mathrm{BaSO}_{4}\right)$, epsomite
$\left(\mathrm{MgSO}_{4} \cdot 7 \mathrm{H}_{2} \mathrm{O}\right)$ and gypsum $\left(\mathrm{CaSO}_{4} \cdot 2 \mathrm{H}_{2} \mathrm{O}\right)$ (Greenwood and Earnshaw 1984). These dissolved minerals contribute to the mineral content of both surface and groundwater bodies. Sulfate ion concentration in the water samples varied between 0.08 and $10 \mathrm{mg} / \mathrm{L}$ with an average value of $0.86 \mathrm{mg} / \mathrm{L}$. The sulfate concentration $\left(\mathrm{SO}_{4}^{2+}\right)$ in the all experimental water samples were within the permissible limits of $250 \mathrm{mg} / \mathrm{L}$ (WHO 2011). Higher concentration of sulfate in groundwater may be attributed to contamination of untreated industrial and domestic waste and their effluents (Baruah et al. 2008; Jeevanandam et al. 2008, 2012; Boateng et al. 2016). Higher concentration of $\mathrm{SO}_{4}^{2-}$ may cause gastrointestinal irritation particularly when $\mathrm{Mg}^{2+}$ and $\mathrm{Na}^{+}$are also present in drinking water resources (Suthar et al. 2009; Boateng et al. 2016).

According to WHO (2011), the permissible limit of phosphate concentration in drinking water should be below $0.1 \mathrm{mg} / \mathrm{L}$. Phosphate $\left(\mathrm{PO}_{4}^{3-}\right)$ concentration in the water samples ranged from 0.08 to $2.3 \mathrm{mg} / \mathrm{L}$ with an average value of $0.48 \mathrm{mg} / \mathrm{L}$. Some of the water samples exceeded the permissible limits of phosphate concentration. Most of the people around the mine area use Triple Super Phosphates (TSP) for agricultural purposes. So, the presence of phosphates in water may be due to anthropogenic origin. The concentration of the bi-carbonate ranged from 5 to $87.5 \mathrm{mg} / \mathrm{L}$. Bicarbonate is responsible for the alkalinity of groundwater. The bicarbonates are probably derived from weathering of silicate rocks, dissolution of carbonate precipitates, atmospheric and soil $\mathrm{CO}_{2}$ gas (Jeong 2001; Subramani et al. 2005; Kumar et al. 2011; Boateng et al. 2016). 
The concentration of nitrate ion in water samples ranged from 0.07 to $0.71 \mathrm{mg} / \mathrm{L}$ with an average value of $0.35 \mathrm{mg} / \mathrm{L}$ were found within the permissible limits. The source of $\mathrm{NO}_{3}^{-}$may be from the high infiltration of soil layer and anthropogenic activities. Nitrate may occur as an intermediate product during the nitrification process of ammonia and also may be from the use of ANFO (Ammonium Nitrate Fuel-Oil Mixture) during blasting work in mining activities. The presence of high nitrate concentration in the drinking water may increases the possibility of gastric cancer and some other potential hazards to the pregnant women. The concentration of ammonium ion in the water samples varied from 0.22 to $1.07 \mathrm{mg} / \mathrm{L}$ with a mean concentration of $0.7 \mathrm{mg} / \mathrm{L}$. The threshold odor concentration of ammonia in water is approximately $1.5 \mathrm{mg} / \mathrm{L}$. A taste threshold limit of $35 \mathrm{mg} / \mathrm{L}$ has been proposed by the WHO (1996). Chloride concentration in the water may result from the evaporation of the chloride bearing minerals which are soluble to the water, encroachment of the saline water to the fresh water zone and different anthropogenic activities. Chloride ion concentration in the experimental samples ranged between 0.71 and $73.84 \mathrm{mg} / \mathrm{L}$ with a mean value of $9.73 \mathrm{mg} / \mathrm{L}$. The carbon dioxide that is dissolved by the naturally circulating water appears in chemical analysis principally as carbonate ions. Carbonate ion concentration in the water samples ranged from 4.3 to $18 \mathrm{mg} / \mathrm{L}$ with a mean concentration of $9.35 \mathrm{mg} / \mathrm{L}$.

\section{Application of Gibbs plot}

Gibbs plot (Fig. 6) is used to interpret the effect of hydrogeochemical processes such as precipitation, rock-water interaction and evaporation on groundwater geochemistry (Boateng et al. 2016). With a view to discerning the source of contamination of water in an area, Gibbs ratio (GR) plot is a useful tool to find the interaction between rock and water. The concentration of dissolved ions in groundwater samples are generally governed by lithology, nature of geochemical reactions and solubility of interaction rocks. The functional sources of dissolved ions can be broadly assessed by plotting the samples, according to the variation in the ratio of $\mathrm{Na}^{+} /\left(\mathrm{Na}^{+}+\mathrm{Ca}^{2+}\right)$ and $\mathrm{Cl}^{-} /$ $\left(\mathrm{Cl}^{-}+\mathrm{HCO}_{3}^{-}\right)$as a function of TDS (Gibbs 1970).

$$
\begin{aligned}
& \text { GR-I (for anion) }=\frac{\mathrm{Cl}^{-}}{\mathrm{Cl}^{-}+\mathrm{HCO}_{3}^{-}} \\
& \text {GR-II (for cation) }=\frac{\mathrm{Na}^{+}+\mathrm{K}^{+}}{\mathrm{Na}^{+}+\mathrm{K}^{+}+\mathrm{Ca}^{2+}}
\end{aligned}
$$

where all ions are represented as meq/L.

Gibbs ratios for the all samples are plotted against TDS (ppm) in Fig. 6 to know whether the groundwater chemistry is due to rock dominance, evaporation dominance or precipitation dominance. From the pot of the Gibbs Ratio plot it is visible that, most of the samples are rock dominated (shown in dash line area) and rest of the samples suggested to be precipitation dominated. This scenario suggests that the evaporation control field increases

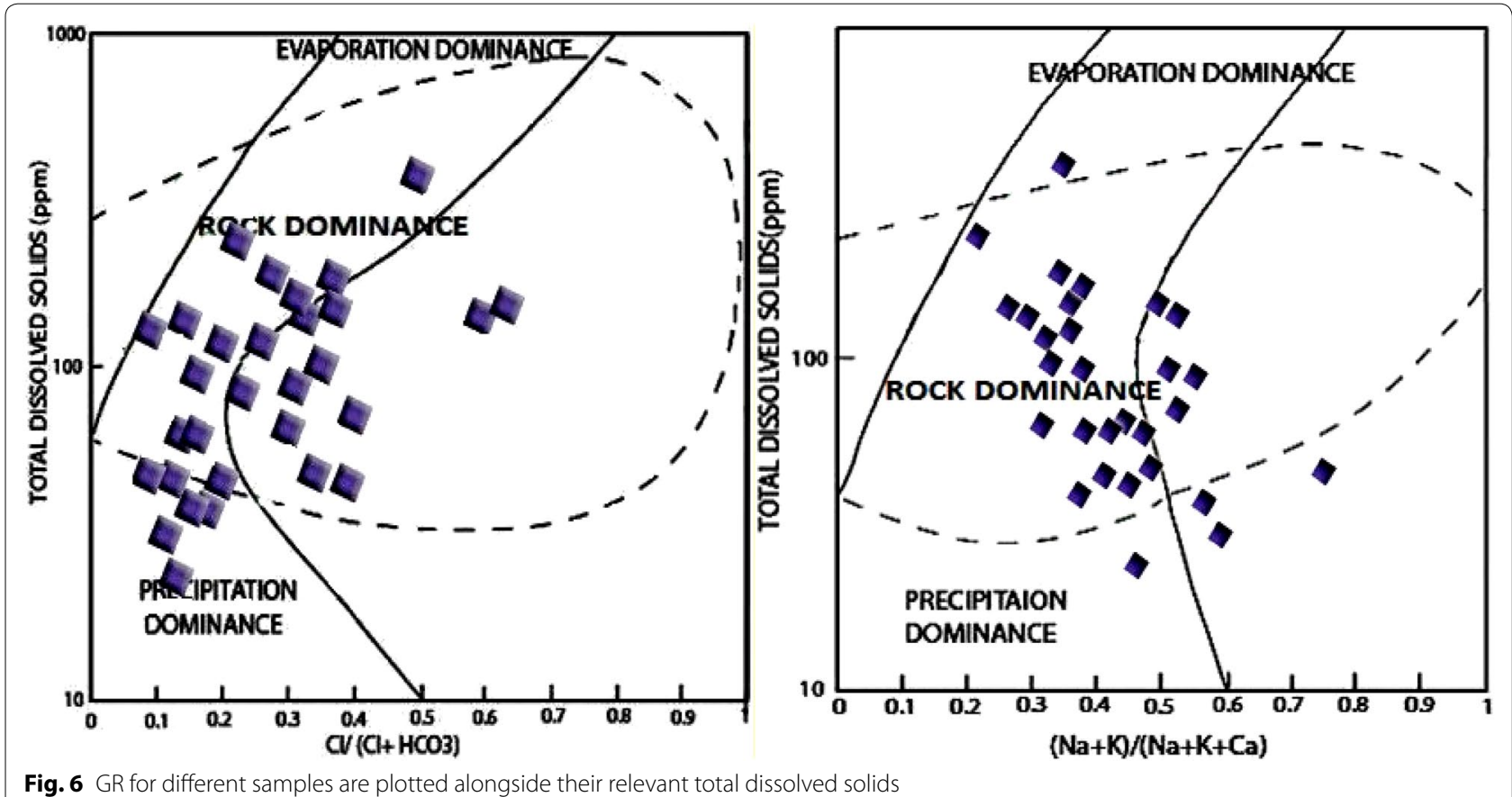

Fig. 6 GR for different samples are plotted alongside their relevant total dissolved solids 
salinity by the increasing ions of $\mathrm{Na}$ and $\mathrm{Cl}$ in relation to increase in TDS and agricultural fertilizers.

\section{Cluster analysis (CA)}

Cluster analysis is a group of multivariate technique whose primary aim is to assemble objects based on the characteristics they possesses (Shrestha and Kazama 2007; Oketola et al. 2013). Hierarchical clustering joins the most similar observations. The levels of similarity at which observations are merged are used to construct a dendrogram (Oketola et al. 2013). Cluster analysis is the unsupervised classification of patterns (observations, data items, or feature vectors) into groups (clusters). The Euclidean distance $\left(\mathrm{D}^{2}\right)$ is the geometric between two objects and can be calculated by the given formula:

$$
\begin{aligned}
\mathrm{D}^{2}= & \left(\mathrm{Z}_{\mathrm{EC} 1}-\mathrm{Z}_{\mathrm{EC} 2}\right)^{2}+\left(\mathrm{ZH}_{\mathrm{TDS} 1}-\mathrm{Z}_{\mathrm{TDS} 2}\right)^{2} \\
& +\left(\mathrm{Z}_{\mathrm{P} 1}-\mathrm{Z}_{\mathrm{P} \mathrm{H} 2}\right)^{2}+\left(\mathrm{Z}_{\mathrm{Ca}^{2+}{ }_{1}}-\mathrm{Z}_{\mathrm{Ca}^{2+}{ }_{2}}\right)^{2}+\cdots
\end{aligned}
$$

The dendrogram for cluster analysis of 31 water samples are shown in Fig. 7. It is visible that the cluster analysis grouped the whole samples into three distinct groups of cluster. Cluster groups in the CA are tabulated in Table 5. Cluster I groups 70.97\% of total samples into two sub-cluster group A1 and A2 whereas, Cluster II is consisted of $22.58 \%$ of samples and finally Cluster-III includes $6.45 \%$ of the total samples. In order to find out the similarity of grouped samples, their grouped physical and chemical parameters analysis are shown collectively in Table 6. The $\mathrm{P}^{\mathrm{H}}$ in the cluster I is comparatively lower (mean $=7.42$ ) than that of water class of cluster II $($ mean $=8.38)$ and cluster III $($ mean $=8.08)$. Likely $\mathrm{P}^{\mathrm{H}}$, EC of the cluster I (average $=98.28$ ) is also show the lowest value than the samples grouped in cluster II (average $=274.71)$ and cluster III (average $=483.5$ ) water samples. Unlike $\mathrm{P}^{\mathrm{H}}$ and $\mathrm{EC}$, turbidity in cluster I is the highest than that of cluster II and cluster III. However,

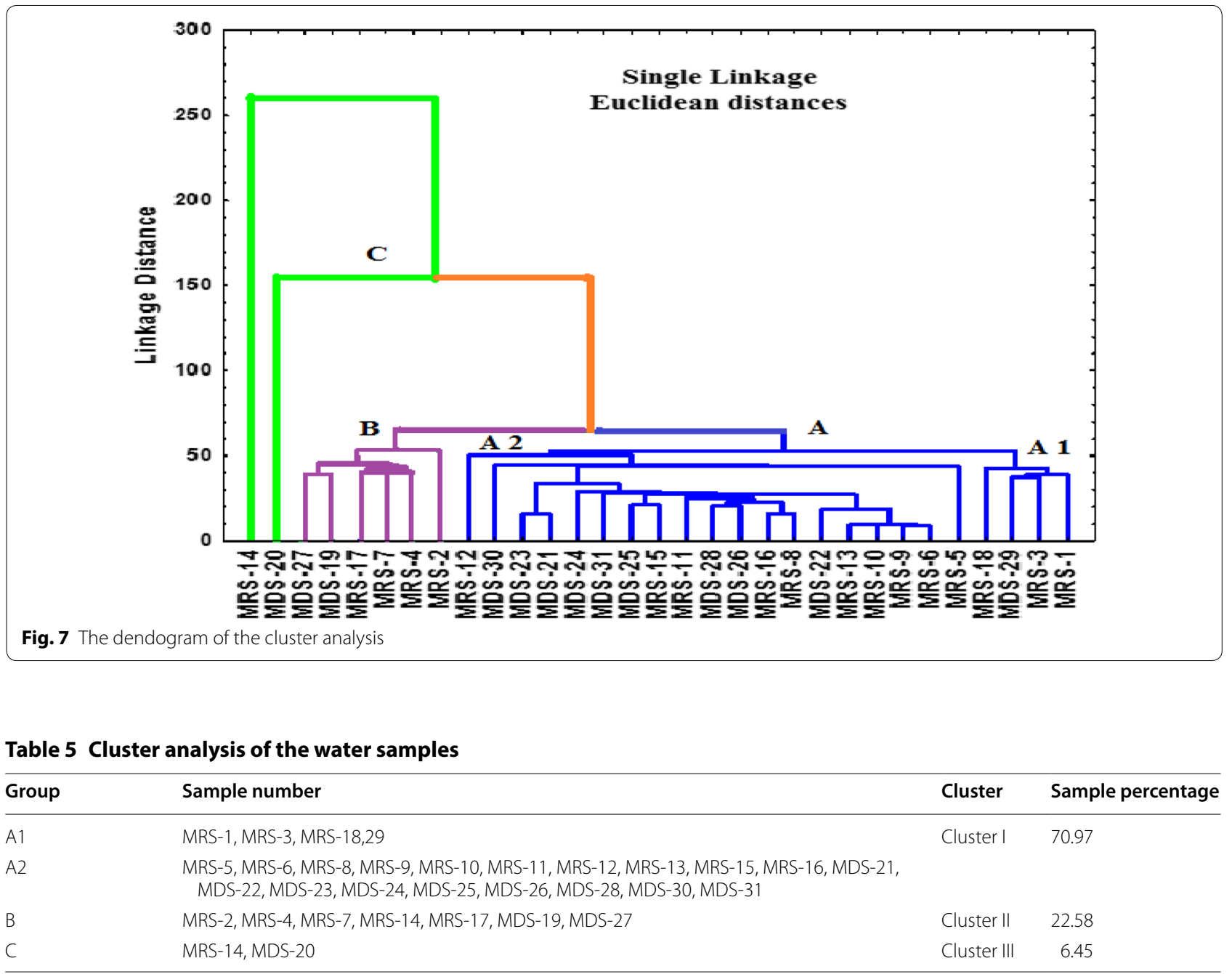


Table 6 Physico-chemical parameters of different clustered groups

\begin{tabular}{|c|c|c|c|c|c|c|c|c|c|c|c|}
\hline & $\mathrm{P}^{\mathrm{H}}$ & $\mathrm{EC}$ & Turbidity & TA & TH & $\mathrm{Ca}^{2+}$ & $\mathrm{Mg}^{2+}$ & $\mathrm{Na}^{+}$ & $\mathrm{K}^{+}$ & $\mathrm{As}^{3+}$ & $\mathrm{Cd}^{2+}$ \\
\hline \multicolumn{12}{|c|}{ Cluster I } \\
\hline Min & 5.3 & 41 & 3 & 5 & 2.5 & 1.3 & 1 & 2.1 & 0.4 & 0 & 0.0008 \\
\hline Max & 9.02 & 194 & 45 & 74 & 43 & 28 & 41 & 53 & 5.72 & 0.0017 & 0.0033 \\
\hline Mean & 7.42 & 98.28 & 12.26 & 24.70 & 15.05 & 9.78 & 9.15 & 11.55 & 2.05 & 0.001 & 0.0018 \\
\hline \multicolumn{12}{|c|}{ Cluster II } \\
\hline Min & 6.6 & 188 & 4 & 14 & 17.5 & 9.4 & 5 & 15.5 & 3.44 & 0 & 0.0009 \\
\hline Max & 8.38 & 587 & 10 & 88 & 87.5 & 51 & 36.5 & 37.9 & 12.2 & 0.0016 & 0.0042 \\
\hline Mean & 7.65 & 274.71 & 6.71 & 38.86 & 41.25 & 26.7 & 14.55 & 22.73 & 6.18 & 0.001 & 0.0027 \\
\hline \multicolumn{12}{|c|}{ Cluster III } \\
\hline Min & 8.03 & 380 & 4 & 59 & 70 & 51 & 15 & 19.7 & 5.72 & 0.0011 & 0.0032 \\
\hline Max & 8.13 & 587 & 8 & 88 & 87.5 & 55 & 36.5 & 37.9 & 12.2 & 0.0014 & 0.0039 \\
\hline \multirow[t]{2}{*}{ Mean } & 8.08 & 483.5 & 6 & 73.5 & 78.75 & 53 & 25.75 & 28.8 & 8.96 & 0.00125 & 0.0036 \\
\hline & $\mathrm{Fe}^{3+}$ & $\mathrm{Zn}^{2+}$ & $\mathrm{Cr}^{3+}$ & $\mathrm{SO}_{4}^{2-}$ & $\mathrm{PO}_{4}^{3-}$ & $\mathrm{SiO}_{2}$ & $\mathrm{NO}_{3}^{-}$ & $\mathrm{Cl}^{-}$ & $\mathrm{NH}_{4}^{+}$ & TDS & $\mathrm{CO}_{3}^{2-}$ \\
\hline \multicolumn{12}{|l|}{ Cluster I } \\
\hline Min & 0.09 & 0.08 & 0 & 0.08 & 0.08 & 11.9 & 0.07 & 0.71 & 0.22 & 24 & 4.3 \\
\hline Max & 0.92 & 0.23 & 0.015 & 2 & 0.64 & 53.84 & 0.63 & 15.76 & 1.07 & 135.8 & 13.6 \\
\hline Mean & 0.34 & 0.13 & 0.002 & 0.39 & 0.32 & 28.25 & 0.31 & 4.52 & 0.68 & 71.49 & 8.39 \\
\hline \multicolumn{12}{|c|}{ Cluster II } \\
\hline Min & 0.16 & 0.1 & 0.0014 & 0.16 & 0.27 & 12.85 & 0.24 & 6.39 & 0.38 & 141.4 & 7.85 \\
\hline Max & 0.52 & 0.3 & 0.005 & 10 & 2.3 & 35.9 & 0.71 & 73.84 & 0.92 & 382 & 18 \\
\hline Mean & 0.34 & 0.2 & 0.002 & 2.43 & 1.04 & 29.51 & 0.47 & 26.57 & 0.70 & 190.01 & 11.71 \\
\hline \multicolumn{12}{|c|}{ Cluster III } \\
\hline Min & 0.24 & 0.3 & 0.0023 & 0.55 & 0.37 & 32.45 & 0.41 & 13.49 & 0.84 & 247 & 15 \\
\hline Max & 0.52 & 0.32 & 0.003 & 1.52 & 0.52 & 37.15 & 0.45 & 73.84 & 1.04 & 382 & 18 \\
\hline Mean & 0.38 & 0.31 & 0.00265 & 1.035 & 0.445 & 34.8 & 0.43 & 43.665 & 0.94 & 314.5 & 16.5 \\
\hline
\end{tabular}

hazardous cadmium concentration in the group of cluster III is the highest than that of cluster I and cluster II.

The concentration of the calcium $\left(\mathrm{Ca}^{2+}\right)$, magnesium $\left(\mathrm{Mg}^{2+}\right)$, sodium $\left(\mathrm{Na}^{+}\right)$, potassium $\left(\mathrm{K}^{+}\right)$, iron $\left(\mathrm{Fe}^{3+}\right)$, zinc $\left(\mathrm{Zn}^{2+}\right)$, chromium $\left(\mathrm{Cr}^{3+}\right)$, Sulfate $\left(\mathrm{SO}_{4}^{2-}\right)$, phosphates $\left(\mathrm{PO}_{4}^{3-}\right)$, nitrates $\left(\mathrm{NO}_{3}^{-}\right)$, chloride $\left(\mathrm{Cl}^{-}\right)$, Ammonia $\left(\mathrm{NH}_{4}^{+}\right)$, TDS and dissolved silica $\left(\mathrm{SiO}_{2}\right)$ ions in cluster I is the lowest in average than that of cluster II and cluster III.

\section{Principal component analysis (PCA)}

Principal component analysis (PCA) is a way of identifying patterns in data, and expressing the data in such a way as to highlight their similarities and differences. PCA is a powerful tool to find the patterns in the high dimension data although the luxury of graphical representation is not available for analyzing data. The pattern of the data reduces the dimension of the data without much loss of data. In case of water quality analysis, PCA is useful tool to identify the ecological aspects of pollutants on environmental systems. PCs were defined according to the criterion that only factors that account for variance greater than 1 (eigenvalue-one criterion) should be included. The rationale for this is that any component should account for more variance than any single variable in the standardized test score space. In order to evaluate the most significant parameters in the assessment of the water quality, principal component analysis have been carried out upon 24 variables for 31 samples from surface and groundwater for identifying the water pollution sources and water quality around the Maddhapara Granite Hard Rock Mine area. An eigenvalue gives a measure of the significance of the factor and factors with the highest eigenvalues are the most significant. Eigenvalues of 1.0 or greater are considered significant (Shrestha and Kazama 2007). Classification of principal components is thus "strong", "moderate" and "weak", corresponding to absolute loading values of $>0.75,0.75-0.50$ and $0.50-0.30$, respectively (Liu et al. 2003). The summary of the PCA including the factor loadings, eigenvalues of each PCs, total variance as well as the cumulative variance generated by Statistica 8.0 software where loading was unrotated for 24 parameters are summarized and strong (medium slate blue color), and moderate (chartreuse color) loading values are 
highlighted in Tables 7 and 8 . Table 8 shows that each five factor has eigenvalue greater than 1 , whose factor 1 (PC 1) (eigenvalue $=9.557823$ ) is the most significant variables which explains $39.82426 \%$ of the total variance. Factor 2 (PC 2) (eigenvalue $=3.060269$ ) is the second significant value that contributes $12.75112 \%$ of the total variance. Factor 3 (PC 3) defines $9.62826 \%$ of the total variance with eigenvalue of 2.310782. Factor 4 (PC 4) and factor 5 (PC 5) possess eigenvalue of 1.870234 and 1.43581 respectively and define 7.79264 and $5.88992 \%$ of the total variance in some respects. Tables 7 and 8 show five factors (PCs) have explained $75.89 \%$ of the total variance. The first factor (PC 1) explained $39.82 \%$ of the total variance and dominated by the sp. conductivity, total alkalinity, alkalinity $\left(\mathrm{HCO}_{3}^{-}\right)$, calcium, potassium, chloride, TDS and carbonate (highlighted by medium slate blue color) inversely strongly. $\mathrm{P}^{\mathrm{H}}$, sodium and zinc (highlighted by chartreuse color) show a moderate and negative correlation with factor 1 (PC 1) representing chemical components due to the geologic feature in the water environment which satisfy the previous published scientific results by Bu et al. 2009. Nevertheless, the $\mathrm{P}^{\mathrm{H}}$ is weakly loaded on F1 (Figs. 8, 9), its negative loading suggests a weak bipolarity of a factor, substantiates the idea of good solubility of limestone at low (acid) $\mathrm{P}^{\mathrm{H}}$ conditions. It is concerned with positive association between

Table 7 Summary of the PCA loading for 24 variables

\begin{tabular}{|c|c|c|c|c|c|}
\hline Variables & Factor 1 & Factor 2 & Factor 3 & Factor 4 & Factor 5 \\
\hline $\mathrm{P}^{\mathrm{H}}$ & -0.505140 & -0.423783 & -0.523819 & 0.281011 & 0.231837 \\
\hline Sp. conductivity & -0.973220 & 0.078222 & 0.062930 & -0.105619 & -0.052161 \\
\hline Turbidity & 0.027478 & -0.437808 & 0.685626 & 0.218108 & -0.157060 \\
\hline Total alkalinity & -0.835965 & -0.389071 & -0.155823 & 0.100161 & 0.047304 \\
\hline Alkalinity $(\mathrm{OH})$ & -0.298613 & -0.443572 & -0.304156 & 0.432541 & -0.020149 \\
\hline Alkalinity $\left(\mathrm{HCO}_{3}\right)$ & -0.854348 & -0.365501 & -0.133041 & 0.060517 & 0.052251 \\
\hline Total hardness & -0.959257 & -0.105187 & 0.034686 & -0.051546 & 0.055754 \\
\hline Iron & -0.176503 & -0.311548 & 0.125313 & 0.259103 & -0.703320 \\
\hline Calcium & -0.917427 & -0.056955 & 0.121062 & -0.094580 & 0.070455 \\
\hline Magnesium & -0.458933 & -0.356458 & -0.138375 & 0.118694 & -0.520944 \\
\hline Sodium & -0.615277 & 0.107953 & 0.049094 & 0.078692 & 0.121033 \\
\hline Potassium & -0.871104 & 0.105514 & 0.060418 & -0.269454 & -0.140015 \\
\hline Arsenic & -0.014235 & 0.364144 & -0.699425 & -0.245118 & -0.361498 \\
\hline Cadmium & -0.450872 & 0.598943 & 0.040729 & 0.214109 & 0.166345 \\
\hline Zinc & -0.722452 & 0.384863 & -0.011331 & -0.468652 & 0.035537 \\
\hline Chromium & -0.029260 & 0.269727 & 0.122538 & -0.544966 & -0.284185 \\
\hline Sulfate & -0.302047 & 0.583734 & 0.107611 & 0.416829 & 0.057136 \\
\hline Phosphate & -0.351122 & 0.592348 & 0.052115 & 0.504778 & 0.008429 \\
\hline Soluble silica & -0.251729 & 0.252323 & -0.793143 & 0.170839 & 0.013400 \\
\hline Nitrate & -0.372521 & 0.430667 & 0.393509 & 0.435109 & -0.044675 \\
\hline Chloride & -0.835263 & 0.230616 & 0.155028 & 0.033166 & -0.119517 \\
\hline Ammonia & -0.350977 & -0.448496 & 0.129445 & -0.199509 & 0.507021 \\
\hline TDS & -0.973249 & 0.057827 & 0.065802 & -0.112613 & -0.037220 \\
\hline Carbonate & -0.885900 & -0.171159 & 0.147483 & -0.192210 & 0.008697 \\
\hline
\end{tabular}

Significant factor loadings are in italics

Table 8 Summary of the PCA including the eigenvalues of each PCs, total variance

\begin{tabular}{llccc}
\hline Factor & Eigen value & \%Total variance & Cumulative eigen value & Cumulative \%variance \\
\hline 1 & 9.557823 & 39.82426 & 9.55782 & 39.82426 \\
2 & 3.060269 & 12.75112 & 12.61809 & 52.57538 \\
3 & 2.310782 & 9.62826 & 14.92887 & 62.20364 \\
4 & 1.870234 & 7.79264 & 16.79911 & 69.99628 \\
5 & 1.413581 & 5.88992 & 18.21269 & 75.88620 \\
\hline
\end{tabular}


$\mathrm{Ca}^{2+}$ and $\mathrm{HCO}_{3}^{-}$which is thought to indicate the process of carbonate dissolution on certain locations which bear out the previous published scientific results by Terzic et al. (2010).
Factor 2 (PC 2) is moderately and positively dominated by cadmium, sulfate and phosphate (highlighted by chartreuse color) and explained $12.75 \%$ of the total variance. It signifies the weathering of rock and anthropogenic

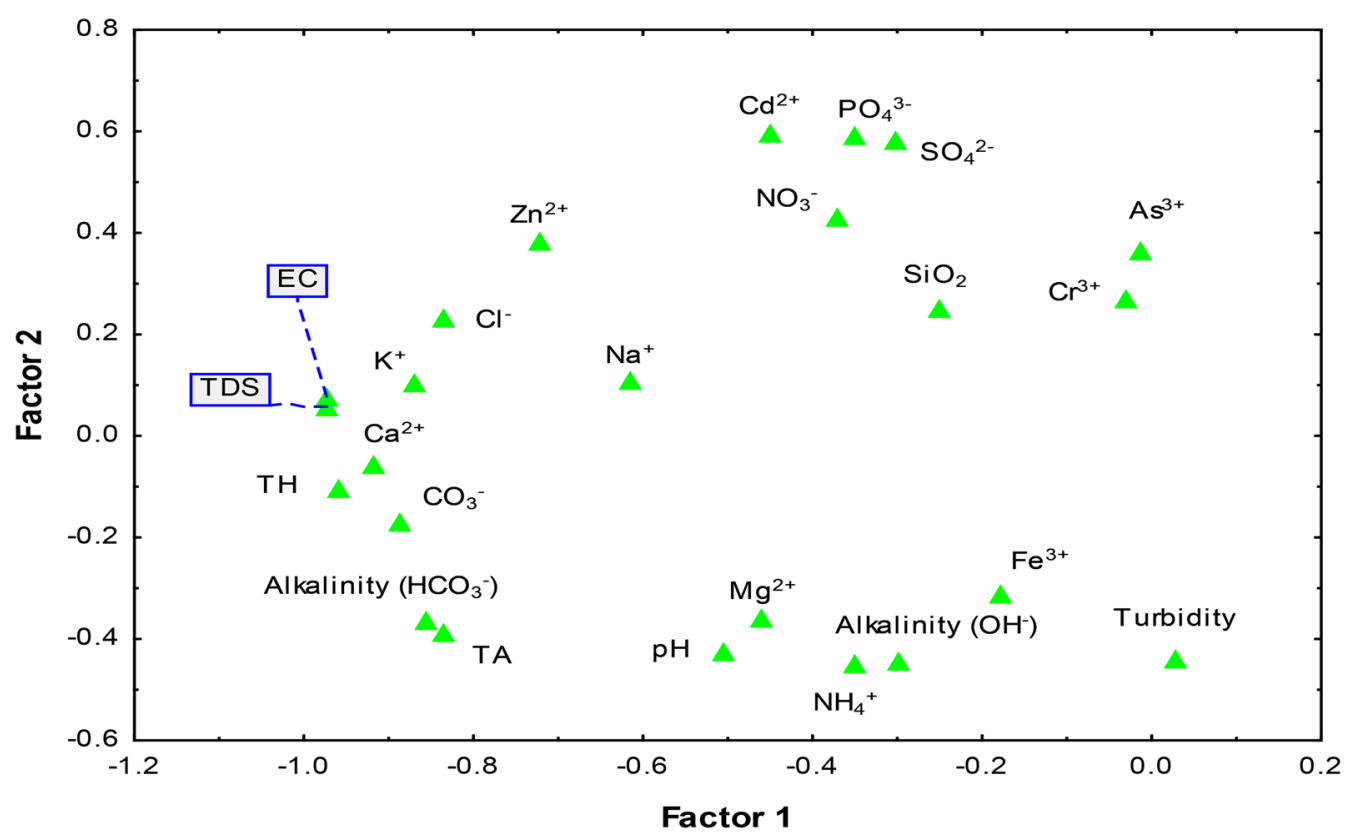

Fig. 8 Factor analysis diagram. Factor loadings: Factor 1 versus Factor 2. Loading: unrotated, extraction: principal components

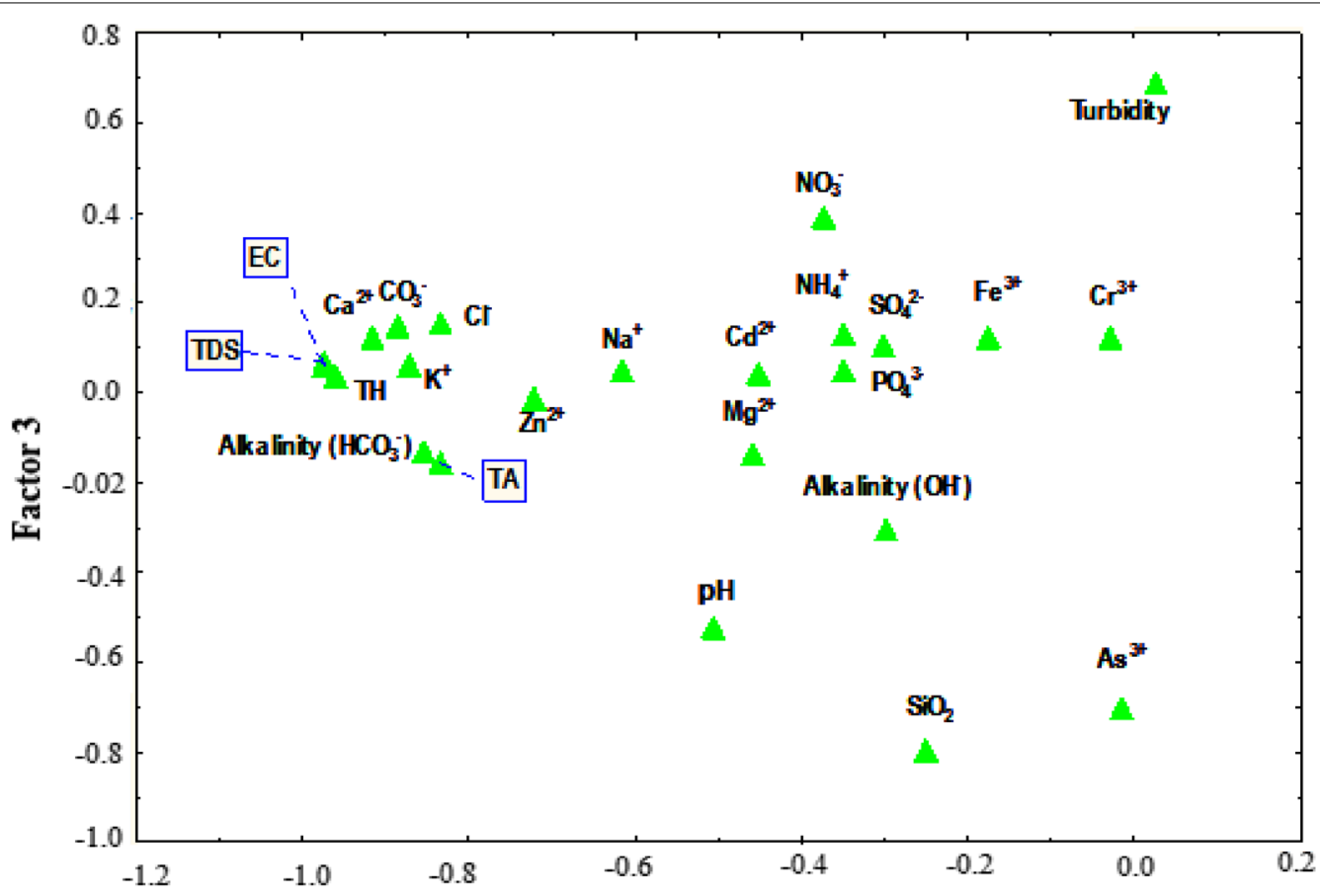

Factor 1

Fig. 9 Factor analysis diagram. Factor loadings: Factor 1 versus Factor 3. Loading: unrotated, extraction: principal components 
impacts on the water contaminations. Figure 8 shows the factor $1 \mathrm{vs}$. factor 2 plot and their level of relationship to each other. Factor (PC 3) is dominated negatively and strongly by the soluble silica and moderately by arsenic. It shows a moderate positive correlation with turbidity. However, factor 3 (PC 3) has explained 9.63\% of the total variance. Figure 9 shows the factor 1 vs. factor 3 plot and their level of relationship to each other. It implies the contamination of water by the aquifer and stockpiled rocks and which strongly recommends the weathering and dissolution of granite rocks found in the study area containing $50.17-74.7 \%$ by weight of silica and its impacts of the water around the area. Factor 4 (PC 4) shows moderate positive and negative correlation with phosphate and chromium respectively with $7.79 \%$ of the total variance. Factor 5 (PC 5) is moderately and hence negatively dominated by the iron (Fe) and magnesium $(\mathrm{Mg})$ and positively with ammonia $\left(\mathrm{NH}_{3}\right)$. Factor 4 and factor 5 may direct the anthropogenic effects due to fertilizer uses in the agricultural purposes and one the most important use should be noted in the mining area is the use of ANFO (Ammonium Nitrate Fuel Oil Mixtures) in order to secondary blasting and hence breaking down of the hard rock in the area to be mined (Table 9).

Nitrogen from untreated or partially treated wastewater discharges and manure may be either organic or ammonium form, while nitrogen from chemical fertilizers will typically be in ammonium or nitrate form (Canter 1997). Ammonia volatilization is a physicochemical process where ammonium-nitrogen is known to be in equilibrium between the gaseous and hydroxyl forms and it is $\mathrm{P}^{\mathrm{H}}$ (with an alkaline $\mathrm{P}^{\mathrm{H}}$ favoring the presence of aqueous forms of $\mathrm{NH}_{3}$ in water, while at acidic or neutral $\mathrm{P}^{\mathrm{H}}$, the ammonium-nitrogen is predominantly in ionic form) and temperature dependent (low temperature ammonium ion predominant, while high temperature ammonia ion present) (Reddy and Patrick 1981; Terzic et al. 2010).

\section{Application of Water Quality Index and the quality of water for various purposes}

The Water Quality Index (WQI) is a single value expression that summarizes numerous parameters and provides a measure of water quality. Water quality indices (WQIs) were calculated for the samples using the concentration of 12 parameters such as $\mathrm{P}^{\mathrm{H}}, \mathrm{EC}, \mathrm{TH}, \mathrm{TDS}, \mathrm{Ca}^{2+}, \mathrm{Mg}^{2+}$, $\mathrm{K}^{+}, \mathrm{Cl}^{-}, \mathrm{SO}_{4}^{2-}, \mathrm{NO}_{3}^{-}, \mathrm{HCO}_{3}^{-}$, and $\mathrm{PO}_{4}^{3-}$. The WQI of the samples ranged from 10.23 to 63.64. According to the calculated value of the WQI, $96.77 \%$ of the experimented samples show excellent and $3.23 \%$ of the samples fall under good quality type water for drinking purposes. Figure 10 shows the minimum, maximum and the average WQI values for three cluster groups. It shows that the cluster I group is the best quality water among the
Table 9 Calculated Water Quality Index and their classification of the samples

\begin{tabular}{llllll}
\hline Sample & WQI & Water type & Sample & WQI & Water type \\
\hline MRS-1 & 31.23008 & Excellent & MRS-17 & 42.11095 & Excellent \\
MRS-2 & 37.06531 & Excellent & MRS-18 & 31.4552 & Excellent \\
MRS-3 & 28.06065 & Excellent & MDS-19 & 26.77772 & Excellent \\
MRS-4 & 35.07572 & Excellent & MDS-20 & 44.10005 & Excellent \\
MRS-5 & 10.23388 & Excellent & MDS-21 & 17.44005 & Excellent \\
MRS-6 & 14.97247 & Excellent & MDS-22 & 19.51724 & Excellent \\
MRS-7 & 37.29106 & Excellent & MDS-23 & 19.94317 & Excellent \\
MRS-8 & 18.25328 & Excellent & MDS-24 & 19.07301 & Excellent \\
MRS-9 & 16.69171 & Excellent & MDS-25 & 20.80748 & Excellent \\
MRS-10 & 16.16417 & Excellent & MDS-26 & 19.08683 & Excellent \\
MRS-11 & 15.65285 & Excellent & MDS-27 & 29.87894 & Excellent \\
MRS-12 & 15.77154 & Excellent & MDS-28 & 19.37103 & Excellent \\
MRS-13 & 15.14981 & Excellent & MDS-29 & 29.33892 & Excellent \\
MRS-14 & 63.64195 & Good & MDS-30 & 25.17631 & Excellent \\
MRS-15 & 21.79876 & Excellent & MDS-31 & 20.55718 & Excellent \\
MRS-16 & 18.54043 & Excellent & & & \\
\hline
\end{tabular}

three groups and there is a visible upward trend along which water quality deteriorates. Moreover the overall status of the quality of water around the mining area has been shown in Fig. 11 which might be helpful to have the proper monitoring program for maintaining sustainable water environ and sound mining operation in the area.

\section{Summary and conclusion}

The water quality around the Maddhapara Granite Mine Area have been evaluated regarding the suitability of water for drinking purposes as well as the identification of the dominating sources of different water quality parameters. Physicochemical analysis of the samples showed the wide variation of $\mathrm{P}^{\mathrm{H}}$ values, high turbid water and appreciable amount of soluble silica in the experimented water samples around the mine sites. All other parameters except these were almost in permissible level based on WHO water quality standards. Based on the Total Hardness (TH) and Electrical Conductivity (EC) values the water samples were found soft to moderately hard and fresh water, respectively. Cluster analysis classified the water samples into three groups such as cluster I (70.97\%), cluster II (22.58\%) and cluster III (6.45\%). Water Quality Index analysis revealed that $96.77 \%$ of the water samples fell under excellent quality and rest 3.23\% of water samples were of good quality types. WQI analyses among the three clustering groups showed that cluster I was of the best quality water and then sequentially cluster II and cluster III. Principal Components Analysis (PCA) expressed that five factors extracted explained $75.89 \%$ of the total variance. The results from the PCA 


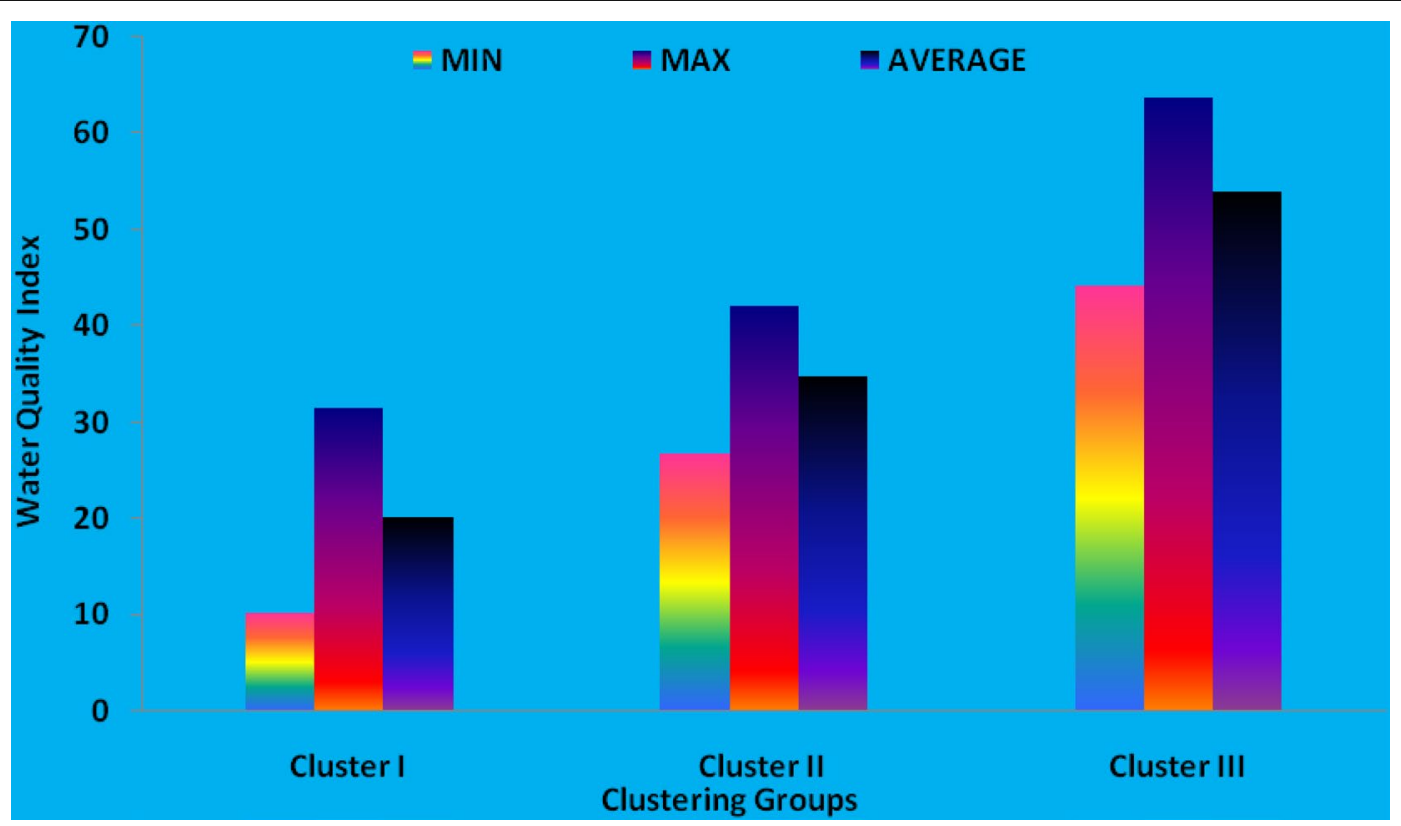

Fig. 10 Comparison of Water Quality Index among the clustering groups with their minimum, maximum, and average values

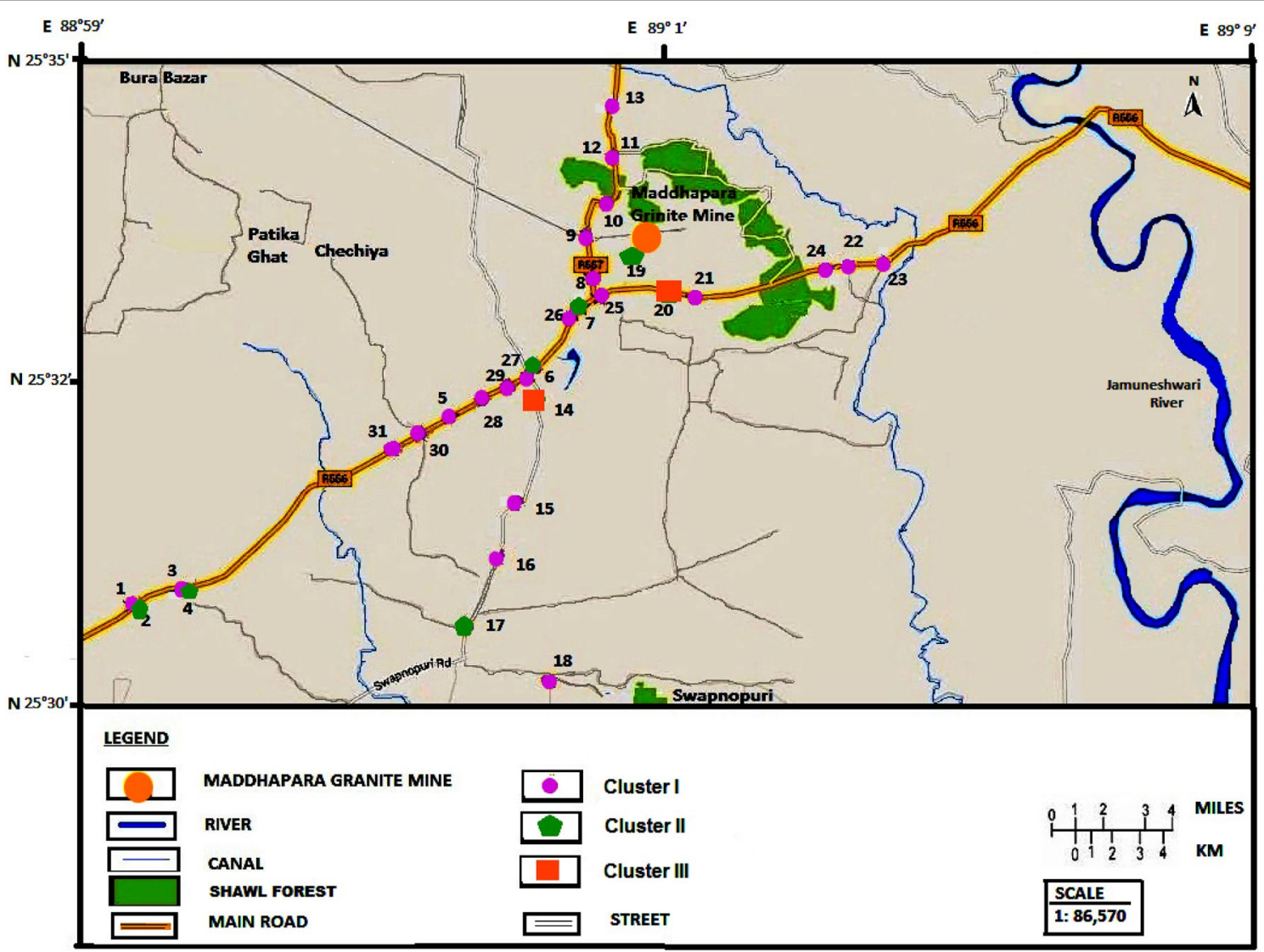

Fig. 11 The status of the quality of water around the mining area. The cluster group I reflects the best quality water of the area 
gave a hint that the water quality in mine area is mainly influenced by weathering of rock, mining, dissolution of ions and anthropogenic activities. The Gibbs ratio plot showed that most of the samples were rock dominated and rest of the samples suggested to be precipitation dominated. This study provides a qualitative measure of the water quality around the Maddhapara Granite Mine area, Dinajpur, which suggests the necessity of the remedial actions to the contaminated sources in order to keep the water safe and reliable for present and future consumption. The main innovative things of this research work is that sample locations have been plotted on map based on Cluster Analysis (CA) and Water Quality Index (WQI) which ultimately help us to understand the water quality in surrounding area. Moreover, it will be helpful in monitoring activities and for further water quality management to prevent the pollution.

\section{Authors' contributions}

MFH contributed to conception, design, and acquisition of data, data analysis and interpretation of data. AAN participated to acquisition of data, data analysis and interpretation of data as well as involved in drafting the primary manuscript. MOF made a contribution to drafting, checking graphs and revising the manuscript critically to fulfill the reviewer comments as well as maintaining the scientific merits with syntactic correctness for final submission of the manuscript. All authors read and approved the final manuscript.

\section{Authors' information}

Dr. M. Farhad Howladar: Associate Professor in the Department of Petroleum and Mining Engineering at Shahjalal University of Science and Technology, Sylhet, Bangladesh. He teaches and undertakes research on Water and soil resources and its relevant environment and management, Geo-statistical application in water and soil environmental analysis, Environmental Geology and Environmental Impact Assessment, Mining waste analysis and its Impact on Public Health and Environmental Pollution as well as Mining and Geological Engineering.

Mohammed Omar Faruque: Assistant Professor in the Department of Petroleum and Mining Engineering at Shahjalal University of Science and Technology, Sylhet, Bangladesh. He teaches and undertakes research on Produced water and Wastewater treatment, Energy and Environment, Biofuel as well as in the field of Fundamentals Engineering.

Md. Abdullah Al Numanbakth: He was the undergraduate student in the Department of Petroleum and Mining Engineering at Shahjalal University of Science and Technology, Sylhet, Bangladesh. Recently, He completed Bachelor of Science (Engineering) degree in Petroleum and Mining Engineering with good academic record.

\section{Acknowledgements}

The authors would like to thank to the Ministry of Education, Bangladesh for the partial financial support to the successful completion of the research work, otherwise it was beyond our reach.

\section{Competing interests}

The authors declare that they have no competing interests.

\section{Publisher's Note}

Springer Nature remains neutral with regard to jurisdictional claims in published maps and institutional affiliations.

Received: 24 November 2016 Accepted: 4 April 2017

Published online: 17 April 2017

\section{References}

Ahmad Z, Qadir A (2011) Source evaluation of physicochemically contaminated groundwater of Dera Ismail Khan area, Pakistan. Environ Monit Assess 175(1-4):9-21

Amadi AN, Yisa J, Okoye NO, Okunlola IA (2010) Multivariate statistical evaluation of the hydrochemical facies in Aba, Southeastern Nigeria. Int J Biol Phys Sci 15(3):326-337

Amadi AN, Nwankwoala HO, Olasehinde PI, Okoye NO, Okunlola IA, Alkali YB (2012) Investigation of aquifer quality in Bonny Island, Eastern Niger Delta, Nigeria using geophysical and geochemical techniques. J Emerg Trends Eng Appl Sci 3(1):180-184

Avvannavar SM, Shrihari S (2008) Evaluation of Water Quality Index for drinking purposes for river Netravathi, Mangalore, South India. Environ Monit Assess 143:279-290

Baruah M, Bhattacharya KG, Patgiri AD (2008) Water quality of shallow groundwater of core city area of Guwahati. In: Proceedings of sixteenth national symposium on environment, Haryana, India, pp 101-106

Bashar K, Karim R, Hossain MS, Chowdhury DA, Rahman MS, Chowdhury MN (2008) Assessment of the groundwater quality of Maddhapara Granite Mine Area, Dinajpur, Bangladesh. Bangladesh Geosci J 14:1-12

Boateng TK, Opoku F, Acquaah SO, Akoto O (2016) Groundwater quality assessment using statistical approach and Water Quality Index in EjisuJuaben Municipality, Ghana. Environ Earth Sci 75:489

Bu H, Tan X, Li S, Zhang Q (2009) Water quality assessment of the Jinshui River (China) using multivariate statistical techniques. Environ Earth Sci 60(8):1631-1639

Canter LW (1997) Nitrates in groundwater. CRC Press, London, p 263

Edraki M, Golding SD, Baublys KA, Lawrence MG (2005) Hydrochemistry, mineralogy, and sulphur isotope geochemistry of acid mine drainage at the Mt. Morgan mine environment, Queensland, Australia. Appl Geochem 20:789-805

EQS (2004) Environmental quality standards. Department of Environment, Bangladesh

Gbadebo AM, Taiwo AM, Adeola AJ (2013) Assessment of dissolved silica content of groundwater from Southwestern Nigeria. J Hum Ecol 43(3):273-279

Gibbs RJ (1970) Mechanism in controlling world water chemistry. Sciences 170:795-840

Gomshei MM, Allen DM (2000) Potential application of oxygen-18 and deuterium in mining effluent and acid rock drainage studies. Environ Geol 39:767-773

Greenwood NN, Earnshaw A (1984) Chemistry of the elements. Pergamon Press, Oxford

Hossain G, Howladar MF, Nessa L, Ahmed SS, Quamruzzaman C (2010) Hydrochemistry and classification of groundwater resources of Ishwardi municipal area, Pabna district, Bangladesh. Geotech Geol Eng 28(5):671-679

Howladar MF (2013) Coal mining impacts on water environs around the Barapukuria Coal Mining Area, Dinajpur, Bangladesh. Environ Earth Sci 70(1):215-226

Howladar MF (2017) An assessment of surface water chemistry with its possible sources of pollution around the Barapukuria Thermal Power Plant Impacted Area, Dinajpur, Bangladesh. Groundw Sustain Dev. doi:10.1016/i.gsd.2017.03.004

Howladar MF, Rahman MM (2016) Characterization of underground tunnel water hydrochemical system and uses through multivariate statistical methods: a case study from Maddhapara Granite Mine, Dinajpur, Bangladesh. Environ Earth Sci 75:1501. doi:10.1007/s12665-016-6309-7

Howladar MF, Hasan MM, Islam S, Shine FMM, Quamruzzaman C (2013) Gas blowout impacts on ground water environs around the Tengratila gas field, Chattak, Bangladesh. J Water Resour Prot 5:164-170

Howladar MF, Deb PK, Muzemder ATMSH, Ahmed M (2014) Evaluation of water resources around Barapukuria Coal Mine Industrial Area, Dinajpur, Bangladesh. Appl Water Sci 4:203-222

Howladar MF, Deb PK, Muzemder ATMSH (2017) Monitoring the underground roadway water quantity and quality for irrigation use around the Barapukuria Coal Mining Industry, Dinajpur, Bangladesh. Groundw Sustain Dev 4:23-34. doi:10.1016/j.gsd.2016.11.002 
Jeevanandam M, Benaventea D, Ordoneza S, García-del-Curab MA (2008) Multivariate statistical techniques for evaluating the effects of brecciated rock fabric on ultrasonic wave propagation. Int J Rock Mech Min Sci 45(4):609-620 Jeevanandam M, Nagarajan R, Manikandan M, Senthilkumar M, Srinivasalu S, Prasanna MV (2012) Hydrogeochemistry and microbial contamination of groundwater from Lower Ponnaiyar Basin, Cuddalore District, Tamil Nadu, India. Environ Earth Sci 67(3):867-887

Jeong CH (2001) Effects of land use and urbanization on hydrochemistry and contamination of groundwater from Taejon area, Korea. J Hydrol 253:194-210

Kumar SK, Chandrasekar N, Seralathan P, Godson PS, Magesh NS (2011) Hydrogeochemical study of shallow carbonate aquifers, Rameswaram Island, India. Environ Monit Assess 184(7):4127-4139

Liu CW, Lin KH, Kuo YM (2003) Application of factor analysis in the assessment of ground water quality in a blackfoot disease area in Taiwan. Sci Total Environ 30:77-89

Martinello K, Oliveira MLS, Molossi FA, Ramos CG, Teixeira EC, Kautzmann RM, Oliveira MLS, Ward CR (2014) Direct identification of hazardous elements in ultra-fine and nanominerals from coal fly ash produced during diesel co-firing. Sci Total Environ 470:444-452

McMurry J, Fay RC (2004) Hydrogen, oxygen and water". In: Hamann KP (ed) Chemistry, 4th edn. Pearson Education, New Jersey, pp 575-599

Mendie U (2005) The nature of water. The theory and practice of clean water production for domestic and industrial use, Lacto-Medals Publishers, Lagos, pp 1-21

Mishra PC, Patel RK (2001) Study of the pollution load in the drinking water of Rairangpur, a small tribal dominated town of North Orissa. Indian J Environ Ecoplan 5(2):293-298

Naik S, Purohit KM (2001) Studies on water quality of river Brahmani in Sundargarh district, Orissa. Indian J Environ Ecoplan 5(2):397-402

NAMNAM (2000) Hydrogeological survey report of Maddhapara hardrock mining project. Unpublished Report of MHMP

Offodile ME (1983) The occurrence and exploitation of groundwater in Nigeria basement rocks. J Min Geol 2:131-146

Oketola AA, Adekolurejo SM, Osibanjo O (2013) Water quality assessment of river Ogun using multivariate statistical techniques. J Environ Prot 4:466-479

Pawar RS, Panaskar DB, Wagh VM (2014) Characterization of groundwater using Water Quality Index of Solapur industrial belt, Maharashtra, India. Int J Res Eng Technol 2(4):31-36

Rahman A (1987) Geology of madhyapara area, dinajpur districts, Bangladesh. Records of geological survey of bangladesh, vol 5. Geological Survey of Bangladesh, Chittagong, Bangladesh, p 61

Rahman MM, Naidu R, Bhattacharya P (2009) Arsenic contamination in groundwater in the Southeast Asia region. Environ Geochem Health 31:9-21

Ramos CG, Querol X, Oliveira MLS, Pires K, Kautzmann RM, Oliveira LFS (2015) A preliminary evaluation of volcanic rock powder for application in agriculture as soil a remineralizer. Sci Total Environ 512-513:371-380

Reddy KR, Patrick WH (1981) Nitrogen transformations and loss in flooded soils and sediments. CRC Crit Rev Environ Control 13(4):273-303
Ribeiro L, Kretschmer N, Nascimento J, Buxo A, Rotting TS, Soto G, Soto M, Oyarzun J, Maturana H, Oyarzun R (2014) Water quality assessment of the mining-impacted Elqui River Basin, Chile. Mine Water Environ 33:165-176

Rodriguez-Iruretagiiena A, Fdez-Ortiz de Vallejuelo S, Gredilla A, Ramos CG, Oliveira MLS, Arana G, De Diego A, Madariaga JM, Silva LFO (2015) Fate of hazardous elements in agricultural soils surrounding a coal power plant complex from Santa Catarina (Brazil). Sci Total Environ 508:374-382

Sahu P, Sikdar PK (2008) Hydrochemical framework of the aquifer in and around East Kolkata wetlands, West Bengal, India. Environ Geol 55:823-835

Sanchís J, Božović D, Al-Harbi NA, Silva LF, Farré M, Barceló D (2013) Quantitative trace analysis of fullerenes in river sediment from Spain and soils from Saudi Arabia. Anal Bioanal Chem 405(18):5915-5923

Shrestha S, Kazama F (2007) Assessment of surface water quality using multivariate statistical techniques: a case study of the Fuji river basin. Jpn Environ Model Softw 22(4):464-475

Simeonov V, Stratis JA, Samara C, Zachariadis G, Voutsa D, Anthemidis A, Sofoniou M, Kouimtzis T (2003) Assessment of the surface water quality in Northern Greece. Water Res 37:4119-4124

Singh DF (1992) Studies on the Water Quality Index of some major rivers of Pune, Maharashtra. Proc Acad Environ Biol 1(1):61-66

Singh KP, Malik A, Mohan D, Sinha S (2004) Multivariate statistical techniques for the evaluation of spatial and temporal variations in water quality of Gomti River (India)—a case study. Water Res 38:3980-3992

Srivastava PK, Singh M, Gupta M, Singh N, Kharwar RN, Tripathi RD, Nautiyal CS (2015) Mapping of arsenic pollution with reference to paddy cultivation in the middle Indo-Gangetic Plains. Environ Monit Assess 187:198

Subba RN (1997) Studies on Water Quality Index in hard rock terrain of Guntur district, Andhra Pradesh, India. In: National seminar on hydrology of Precambrian terrains and hard rock areas, pp 129-134

Subramani T, Elango L, Damodarasamy SR (2005) Groundwater quality and its suitability for drinking and agricultural use in Chithar River Basin, Tamil Nadu, India. Environ Geol 24:194-202

Suthar S, Bishnoi P, Singh S, Mutiyar PK, Nema AK, Patil NS (2009) Nitrate contamination in groundwater of some rural areas of Rajasthan, India. J Hazard Mater 171:189-199

Terzic J, Peh Z, Marković T (2010) Hydrochemical properties of transition zone between fresh groundwater and seawater in karst environment of the Adriatic islands, Croatia. Environ Earth Sci 59(8):1629-1642

Tezza VB, Scarpato M, Oliveira LFS, Bernardin AM (2015) Effect of firing temperature on the photocatalytic activity of anatase ceramic glazes. Powder Technol 276:60-65

Tiwari TN, Mishra MA (1985) A preliminary assignment of Water Quality Index of major Indian rivers. Indian J Environ Prot 5:276-279

WHO (1996) Guidelines for drinking-water quality. In: Health criteria and other supporting information, 2nd edn, vol 2. WHO, Geneva. ISBN 978924 1547611

WHO (2011) Guidelines for drinking-water quality. In: Health criteria and other supporting information, 4th edn, WHO, Geneva. ISBN 9789241548151

Zhu C, Anderson G (2002) Environmental applications of geochemical modelling. Cambridge University Press, Cambridge

\section{Submit your manuscript to a SpringerOpen ${ }^{\circ}$ journal and benefit from:}

- Convenient online submission

- Rigorous peer review

- Immediate publication on acceptance

- Open access: articles freely available online

- High visibility within the field

- Retaining the copyright to your article

Submit your next manuscript at springeropen.com 